\title{
Natural resource degradation tendencies in Ethiopia: a review
}

\author{
Simachew Bantigegn Wassie ${ }^{*}$ (i)
}

\begin{abstract}
Background: Ethiopia is gifted with abundant natural resources of adequate landmass, fertile soil, favorable climate, water, wildlife, and others. Many of its resources are not properly identified, well managed, and fully exploited. The concern of this review is collating the current state of knowledge about the status of land, water, forest, rangeland and wildlife resources, and hence, assesses their degradation tendencies.

Results: In Ethiopia, natural resources are under the influence of various interconnected factors like population pressure, agricultural expansion, migration, rapid urbanization, resettlement, climate change, and environmental pollution. Its huge population number had been putting a great burden on the sustainability of almost all types of natural resources. There is, therefore, serious degradation of land, water, forest, rangeland, and wildlife resources that appear to feed off each other. This results in severe soil loss, low vegetative cover, unsustainable farming practice, continuous use of dung and crop residues for fuel, overgrazing, and destruction and/or migration of wildlife, which again are intensifying the degradation of available resources in a vicious circle. The process ends with amplified environmental consequences such as water quality deterioration, biodiversity decline, and averts ecosystem services. It further recapitulates towards diverse socio-economic problems, political instability, marginalization, poverty, and recurrent natural hazards. The Ethiopian governments have taken several steps to address these problems like launching soil and water conservation campaign, tree planting programs, and others; success to date, however, has been limited.
\end{abstract}

Conclusions: Special attention has to be given to properly manage the natural resources and ecosystems; so that, it can continue to provide the goods and services the population need.

Keywords: Natural resource, Degradation, Land, Water, Forest, Wildlife, Rangelands, Ethiopia

\section{Introduction}

The term 'Resource' had no special attention until the early twentieth century. It was only in 1933 when the renowned professor of economics Erich W. Zimmermann publicized his prominent work "Concept of Resource" that the idea became popular (Zimmermann 1933). According to the old school of thinkers, resource literally means nature. Natural things good or bad, effective or ineffective were all considered as resources even though there exist little chance for it to be used under the socio-economic conditions of the time (Poudel 2012).

\footnotetext{
*Correspondence: simyebb@gmail.com

Department of Geography and Environmental Studies, Bahir Dar University, P.O Box 79, Bahir Dar, Ethiopia
}

However, this view of resources, out of any locus to their functional aspect, is not acceptable for modern thinkers. To them, resource is a source or supply from which a benefit is produced and has some utility (Campbell et al. 2013). Among the modern thinkers, Zimmermann and his supporters hold that resources are those elements from the earth which are capable of bringing human welfare. Such resources are naturally occurring and exploitable ones that the society recognize it to be valuable for its socio-economic and material well-being (Araral 2014). Accordingly, the term 'resource' conveys a sense of free goods, human-centric use and commodification of nature (Berkes 2010).

Traditionally, three broad categories of resources had been identified by economists such as natural 
resources, human resources, and capital resources. Natural resources are the resources of the earth derived from the physical environment which are not made by people but can be used by them (Berkes 2010). They are the precious gifts of nature to human beings and other life forms (Gogoi 2013). However, natural resources are not evenly distributed athwart countries or areas of the world (Campbell et al. 2013). Some countries might be endowed with varieties of natural resources in excess reserves, some others with few types and small reserves, and even others may not have any resource at all (Downey et al. 2010). By the same token, a country may have an excess of one or more resource types and scarcity of others. Ethiopia is gifted with abundant natural resources of adequate landmass, fertile soil, sufficient rainfall and water, favorable climate, wildlife, and more other resources (Alemu 2017; Baye 2017). Many of its resources are not properly identified nor fully exploited.

Ethiopia is one of the poorest countries in the world where its economy is heavily dependent on agriculture (Baye 2017) and the natural resources for subsistence (Nune et al. 2013; Zegeye 2018). Agriculture is known to be a resource-intensive enterprise (Cassman et al. 2003). Agricultural extensification to produce more food for the rapidly growing population is causing unprecedented changes in the near-natural environments like land, forest, water, grassland, and wildlife (Tolessa et al. 2019). So as to use the available resources optimally and achieve sustainability, it is quite essential to have the information on existing resource use problems, management trends, and its state of occurrence (Ketema et al. 2020). In doing so, proper resource conservation and management options can be determined, and sustainable resource use planning easily be framed (Berkes 2010).

In the natural resources literature, review works are very important to summarize the current state of knowledge, draw lessons from different resource development and protection experiences, create consensus on divergent approaches, and even to determine future research needs. Although several studies have been conducted on various types of natural resource issues in many parts of the world, the author confirms that there are limited studies in underdeveloped countries, particularly in Ethiopia. This drawback is highly noticeable basically on issues of natural resource conservation and management practices, their degradation tendencies, and allied socioeconomic implications.

Among the published empirical studies, Birhanu (2014) has made a review of environmental degradation and management conditions in Ethiopian highlands and compiled the lessons learned. In the same year, Kebede et al. (2014) studied natural resource use conflicts in the Bale Mountains National Park. It deals with conflicts over the use of wildlife, forest, land, and water resources in the park and thus assesses people's attitude there. Both of the studies were site-specific which failed to consider the case in the other parts of the country. Besada (2017) also studied on natural resource exploitation by examining Ethiopia's economic and social development through a land governance lens. Similarly, Assefa and Hans-Rudolf (2017) has discussed on natural resource management practices at the Gamo Highland of Ethiopia. They tried to explore the indigenous and local knowledge used to manage soil, forestland, grazing land, and farmlands at that particular place. However, such studies and many others used in this paper were emphasizing either on one type of natural resource or somewhat piecemeal in their focus in the context of a specific site or geographical area.

In such gaps, there is a need to organize a review paper taking into account several journal articles, peer-reviewed books, conference proceedings, policy documents, and others produced on issues of natural resources. Therefore, the concern of this review is on those major natural resources such as land, water, forest, rangeland, and wildlife which is considered as a resource base for the Ethiopian population. It is aimed at collating the current state of knowledge about the status of such natural resources, management trends, and their degradation tendencies.

\section{Methods}

The methodological approach adopted in this publication was a literature search and synthesis of relevant peerreviewed articles and related literature. The selection of literature was mainly based on search engines and platforms from Google Scholar, Web of Science, Research Gate, Science Direct, and many other scientific journal publishing websites. Besides, citations in key documents were followed to identify additional relevant publications. This review did not cover every aspect of the natural resource management and degradation literature but focused on publications of most relevant ones. As source material, peer-reviewed papers, institutional publications, and very few unpublished sources (related Ph.D. dissertations and MSc theses) were included. However, the peer-reviewed ones were given higher priority in shaping the conclusion of the paper, while unpublished sources served as background material and sources of supplementary reading.

Several keywords were used in searching English-language electronic papers available up to the end of July 2020. These include agroforestry; afforestation; conservation; conservation agriculture; consumption pattern; climate change; degradation; ecotourism; environmental degradation; environmental communication; forest; global warming; livestock; resource; natural resource; 
resource use conflict; management; environmental pollution; resettlement; lifestyle; land; water; soil; rangeland; urbanization; Ethiopian highlands; population growth; natural resource degradation; reforestation; resource conflict; Wildlife; and Ethiopia. As a result, more than 1150 papers were retrieved from the search hits. From these, a total of 280 papers were used for review and synthesis. Finally, by avoiding duplications, only 194 papers that include original research articles $(n=126)$, reviews $(n=21)$, books and book sections $(n=19)$, working papers and conference proceedings $(\mathrm{n}=5)$, policy documents $(n=2)$, and organizational reports $(n=21)$ were reviewed and combined.

\section{The state of natural resources in Ethiopia}

In Ethiopia, where more than $80 \%$ of the population is living in rural areas (Beyene 2015; CSA 2015) and depend on subsistence small scale agriculture (Alemu 2017), securing food and livelihood is inseparably linked to the exploitation of natural resources (Baye 2017; Nigussie et al. 2018). Intense pressure from various human activities, and the application of improper farming and management practices had been posing serious threats to the sustainability of the natural resources and maintenance of balanced ecosystems (Gebreselassie et al. 2016; Marques et al. 2016).

There exist widespread problem related to intensive cultivation, overgrazing, deforestation, soil erosion, water scarcity, livestock fodder, and fuelwood crisis (Hurni et al. 2010; Kassa et al. 2016). All these aspects are often interacting with one another ensuing a reinforcing cycle of poverty, food insecurity, and natural resources degradation trap (Azadi et al. 2018). The problem manifests itself in recurring drought and famine affecting millions of people which also has an impending effect on the nation's economic development (Dejene 2003). The state of natural resources in Ethiopia is under the influence of various interconnected factors such as population pressure, migration and resettlement, land-use changes for agriculture, environmental pollution, the change in climate, and rapid change in the lifestyle of people among others.

\section{Population pressure and resettlement}

Population is a vital resource of any country and the most important means for development, and yet a major causative factor for degradation of the environment (Demissie et al. 2017; Belay and Mengistu 2019). Global population is projected to peak up over 9 billion by the mid of this century and may reach 11 billion by the end of the century (FAO 2017) Cohen et al. (2019). emphasized that "Growing populations and economic development around the world are putting unprecedented stress on the natural world." That is, as world population keeps on increasing, and the developing economies are getting involved in unsustainable production systems and consumption patterns, there always exist extreme pressure in almost all types of natural resources (Ariti et al. 2015; Stavi and Lal 2015). The rising population also leads to enormous production of wastes; and thus, increased pressure on arable lands, losses of biodiversity, pollution of air and water are becoming common occurrences. All these are putting remarkable pressure on the environment (Asfaw and Neka 2017) from which natural resources are primarily derived (Meshesha et al. 2014).

Ethiopia is the most populous country in Africa with a higher rate of population growth. Its population was estimated to be over 101 million by 2016 and currently growing at a rate of $2.5 \%$ (Beyene 2015). The majority of the population are making their livelihoods in lands that are now categorized as moderately to severely degraded areas; mostly in the Ethiopian highlands (Birhanu 2014). Unless significant conservation measures are set out and implemented accordingly, many of the moderately degraded lands might be rigorously degraded in the future (Dejene 2003). This often becomes the underlining cause for over-exploitation of the natural resources (Ariti et al. 2015) and subsequent environmental degradations (Minale 2013).

In nations with a continuously rising population, human mobility is highest (Yonas et al. 2013). Human mobility is the term that encompasses all aspects of the population movement. It is understood to cover involuntary internal or cross-border population displacement, voluntary internal migration, and consented relocation or resettlements. Such mobility is facilitated mostly due to the consequential effects of climate change, drought, flooding, deforestation, pollution, resource scarcity, and environmental degradation (Morinière 2012). Regrading to the environment-human mobility link, there is unanswered question, and yet a debatable issue as to whether human mobility is causing environmental degradation or degraded environments are triggering human mobility (Fig. 1).

Resettlement programs in Ethiopia had been considered as a viable solution to the persistent destitution of the rural populations. Nevertheless, it had brought and still instigating significant impacts on natural resources of the environment specifically at the destination areas (Abera et al. 2020). There had been legal resettlement programs implemented by the consent of the government, and the illegal ones executed arbitrarily often causing the degradation of various environmental resources (Dejene 2003; Alemu 2017). The main objective of government resettlement programs was to support food insecure households get access to productive farmlands 


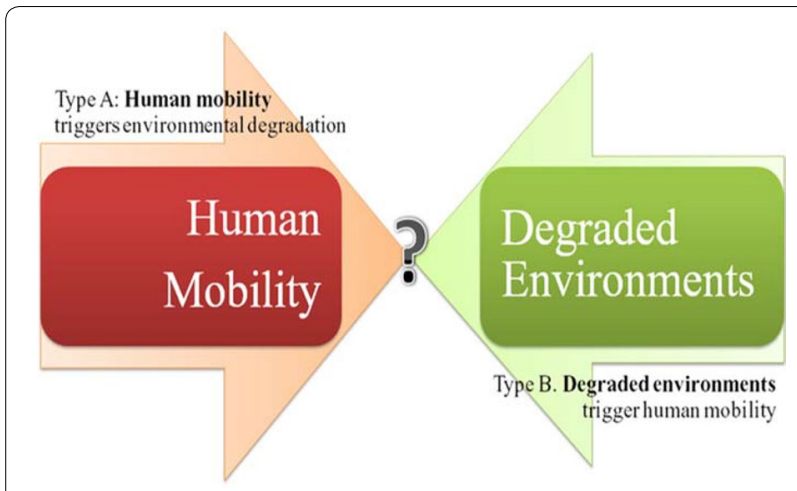

Source: Morinière (2012)

Fig. 1 Environment-Human mobility link
Table 1 Land use/land cover changes in Ethiopia (20012009)

\begin{tabular}{lccr}
\hline $\begin{array}{l}\text { Land use or land } \\
\text { cover }\end{array}$ & \multicolumn{1}{l}{ Years } & \begin{tabular}{l} 
Percent \\
change \\
\cline { 2 - 4 }
\end{tabular} & $\mathbf{2 0 0 1}$ (million ha)
\end{tabular}

Source: Gebreslassie et al. (2016)

and achieve food self-sufficiency. This strategy, in most cases, was taking place through the clearing of natural vegetation particularly in the areas covered by dense forests (Woube 2005). For example, in the resettlement programs implemented between 2000 and 2004, about 1.2 million people (220,000 household heads) were resettled in Amhara, Oromiya, Southern Nations Nationalities and Peoples (SNNP), and Tigray National Regional States. These households had settled by clearing areas which were originally covered by forests causing unprecedented deforestation, land degradation, and associated environmental consequences (Lemenih and Woldemariam 2010).

\section{Land use/land cover changes for agriculture}

Different land use types had been converted to agricultural lands in various places of the world since time immemorial (FAO 2017; Moges and Bhat 2018). Clearing the Earth's forests on a large scale worldwide (UNEP 2012; Marques et al. 2016) and particularly in Ethiopia (Kassa et al. 2016; Belay and Mengistu 2019) for pasture or crop cultivation is ensuing many land damages (Demissie et al. 2017; Tolessa et al. 2019). Clearing of the forest has happened in Ethiopia since the earliest time (Ariti et al. 2015; Mekuriaw 2017), and even become more intense within the past 30 years in the name of investors (Alemu 2017; Ketema et al. 2020). Unregulated commercial land resources exploitation by the investors is causing huge forest destruction, land degradation, and disruption of wildlife resources (Kassa et al. 2016; Besada 2017).

Studies conducted in different parts of Ethiopia within different time periods reported that forestlands/woodlands had been continuously converted to agricultural lands at the highest rate than the other land use types (Meshesha et al. 2014; Ariti et al. 2015; Jaleta et al. 2016; Erkossa et al. 2018; Gashaw et al. 2018; Mekonnen et al.
2018). Similarly, grasslands had also been converted largely to croplands to fulfill the food demand for the increasing population (Mekuriaw and Hurni 2015; Mekonnen et al. 2018; Moges and Bhat 2018). When trees are continuously removed from forests and vegetation biomass cleared, the soils underneath have the tendency to dry out as there are no longer shades, and no enough vegetation to assist the hydrological cycle returns the vaporized water back to the surface (UNEP 2012). With no vegetation cover, landscapes that were once forests and/or rangelands might potentially be changed into barren deserts that possibly avert ecosystem functions and vitiate environmental equilibrium (Gashaw et al. 2018). For instance, results from the calculation made by Gebreslassie et al. (2016) using MODES data presents a dynamic land use/land cover changes in Ethiopia within a decade (2001-2009). Nationally, by taking 2001 as a baseline year, land use changes had shown significant increases in the cropped area (33\%) and shrub lands (7\%). Conversely, substantial losses were reported in forests (26\%), grasslands (11\%), and water bodies ( $8 \%$ ) (Table 1$)$.

A closer look in Table 1 shows that about $12 \%$ of barren land was also brought into use during the period. Regional or locality variations in the rate and amount of land use changes do exist in this kind of investigation. For example, the land use/land cover changes assessment in Arsi Negele district by Mekonnen et al. (2018) shows that agriculture and settlement areas have increased by $250 \%$ and $618 \%$ respectively in the period 1986-2016. The increment is typically due to losses of forests and woodlands which decreased by $72 \%$ and $84 \%$ respectively. Similarly, a study by Tolessa et al. (2019) in Didessa river basin revealed a speedy reduction of wetlands (97.5\%), grasslands (76\%), forest lands (50.6\%), and shrub lands $(38.2 \%)$ that have been taking place in the period 
(1974-2014). Conversely, settlement areas had increased extraordinarily $(17,960.8 \%)$, while the size of cultivated land increased with more than $44.2 \%$ in size.

\section{Climate change and global warming}

It is obviously true that the way humans live their daily lives is continuously affecting the environment (Demissie et al. 2017). Those changes in the environment, in turn, may affect the normal functioning of the ecosystem and can sometimes spell big problem to humans (De Jong et al. 2011; Mekuriaw and Hurni 2015; Bezabih and Mosissa 2017). Nowadays, scientists are notifying that people's way of life from the time when the industrial revolution began is instigating unprecedented changes in the earth's climate system in the form of 'global warming' or 'global climate change.' Climate change with allied extremes is one of wide-ranging global environmental modifications having deleterious effects on natural systems, humans, economies, infrastructure, ecosystems, and biodiversity (Zegeye 2018).

Climate is the key natural resource in which the others depend. Severe changes in climate pattern due to human influence had been threatening biodiversity, and other natural resources (Tessema and Simane 2020). As the climate changes, species that have acclimatized to specific environments are highly affected through the direct-shift or disruption of habitats, influence on the pace of primary productivity and disruption of food chains, disturbance of the nesting, breeding, and migration events as well as the advent of invasive species and extinction of others (IPCC 2014). IPCC (2007) estimated that 20-30\% of the plant and animal species are at risk of extinction if temperatures reach the levels projected to occur by the end of this century.

Ethiopia is one of the most vulnerable countries to the impacts of climate variability and change (Teshome 2016) basically due to its geographical location, rapid population growth, heavy dependence of its economy on agriculture and the natural resources, widespread poverty, and availability of limited human, financial, technical, technological, institutional, and infrastructural resources (Amsalu and Adem 2009). This has led to the occurrence of recurrent droughts and famines, flooding, loss of wetlands and associated ecosystem services, loss of biodiversity, increased incidence of pests and diseases, and decline in agricultural productivity (Gurmessa 2015). Therefore, the change in climate is likely to exacerbate food insecurity, water scarcity, disease epidemics, environmental degradation, and widespread poverty throughout the country (Teshome 2016). For instance, droughts and flooding has affected nearly 21 million people (19.7 million by droughts and the remaining by flooding) between the period 1999 and 2008. It has also caused a significant reduction in water level (volume and surface area) to the extent of complete drying up of many streams, rivers, ponds as well as lakes. In such instances, lakes like Lake Tana, Ziway, Langano, Abijata, and Chamo are shrinking in their water level. Few lakes like Lake Haramaya are already dried up. On the other hand, some other lakes like Beseka, Hawassa, and Abaya are increasing in their water level with the unknown reasons (Zegeye 2018). As an example, aerial photos taken at different times on Lake Beseka have shown that its area coverage was about $3 \mathrm{~km}^{2}$ in the late 1950 s but currently it covers more than $40 \mathrm{~km}^{2}$ (Kebede 2013). According to the same source, the change in volume is due to an increase in the net groundwater flux. Nonetheless, the shrinking and drying up of water bodies and the wetlands will result in scarcity of water, loss of biodiversity and associated livelihoods of people, and disruption of ecological systems in the area and beyond (Teshome 2016).

Generally, different climate extremes are now changing in frequency, duration, timing, intensity, and in spatial extent having a tremendous impact on natural resources and the sustainability of the environment (IPCC 2012). Many developing countries like Ethiopia with less capacity to mitigate and adapt are hit hardest. Accordingly, we should have to work hard to get a well-managed ecosystem that provides regulatory services so that adverse climate impacts on human well-being and other organisms are coming to be reduced (Gebre and Gebremedhin 2019).

\section{Environmental pollution}

Apart from direct and indirect utilization of biotic and abiotic raw materials, we use water, soil, air, biodiversity, and land as habitats and for recreational purposes. Similarly, we use wind power, solar energy, and tidal flows for energy production (Asfaw and Demissie 2012). Furthermore, these resources are again an essential factor of production in farming and forestry. Such resources could also provide a regulatory service as emission sinks, waste dumps as well as for production and maintenance of biodiversity. Unfortunately and inevitably, however, resource utilization throughout the entire supply chain incessantly generates environmental pollution (Appannagari 2017). The term 'Pollution' refers to any undesirable substance added or contaminated to environmental resources which are hazardous or potentially hazardous to human health, safety, and welfare or risky to the normal functioning of other living creatures (Sanbata et al. 2014). Environmental pollution is any change within the environment that affect the integrity of an ecosystem. In most cases, such changes are caused by the action of human beings mainly due to urbanization, industrialization, construction and transportation activities, agricultural and 
land use management practices (Awgchew et al. 2015). Because of various unwanted substances (specks of dust, chemicals, and other toxic matter) released to the environment, the majority of natural resources have been affected, many destroyed and a large portion of it falls under immense threat (Wright et al. 2013).

Practically in Ethiopia, the agriculture sector is found to be the major source of environmental pollution. Application of chemical fertilizers and pesticides (herbicides, fungicides, insecticides, etc.) can easily contaminate living organisms, soil, water, meadows, and other vegetation (Kassa 2017). Studies have shown that from the pesticides applied to agriculture, only $0.1 \%$ reaches the target pest; the other $99.9 \%$ are mostly leaving as a pollutant within the environment. Consequently, it is causing adverse effects such as degrading soil, air, and water quality and affecting non-targeted lives like human beings, cattle, insects, soil organisms, aquatic life, etc. (Nigatu 2016). The recently established large-scale horticulture and floriculture activities around Addis Ababa, in the Rift valley area, and around Bahir Dar in the Amhara region are extensively using chemicals. For instance, Ethiopian floriculture industries use more than 300 chemical types as pesticides and growth regulators; some of which (around 120 chemicals) are even found on the world health organization's negative pesticide list (Kassa 2017). These chemicals can move from the place of the application via leakage, drift, volatilization, and runoff affecting land, air, and water (surface and groundwater) (Alemu 2017).

It is obviously true that about $99 \%$ of the population in Ethiopia uses traditional biomass fuels, such as wood, dung, charcoal, or crop residues to meet household energy needs (Nune et al. 2013). This has caused air pollution which continuously affects human health, and also trigger global warming. In such cases, indoor air pollution from biomass fuel is responsible for 50,320 annual under- 5 year children deaths accounting for $4.9 \%$ of the national burden of disease in the country (Sanbata et al. 2014). At the same time, pollution due to emissions from motor traffic and industrialization processes have also their own share in polluting the environment (Tefera et al. 2016).

Chemical wastes and byproducts from industries and unmanaged urban waste disposal from major cities in open landfill sites are continuously polluting the environment (Gebre and Debelie 2015). For instance, many of the leather processing industries in Ethiopia lack proper waste treatment methods. By its very nature, leather processing involves soaking, fleshing, washing, etc. to remove dirt, flesh, salt, and other foreign substances by making use of water. As a result, different things like salt, pesticides, flesh, hair, suspended solids, sulfate, ammonia, base, chlorides, acid, and other oxygen demanding substances might be released into the surrounding water bodies. Due to this, rivers including Akaki, Awash, Modjo, etc. are being polluted by the tannery sector (Reda 2016). This is also becoming a case for contamination of underground water, soils, and the poisoning of food resources which potentially cause serious health complications to the adjacent community (Gebre and Debelie 2015).

Therefore, land, air, and water pollutions are posing long-term cumulative impacts on the health of humans and other life forms, the availability of natural resources and the quality of the environment in which they occur (Wright et al. 2013). Seriously polluted natural resources have become obsolete in value as pollution makes it harsh for the sustainability of biotic and abiotic components (Baye 2017).

\section{The urban-rural nexus}

Nowadays, the world is getting more urbanized than ever (Gebre and Gebremedhin 2019). In the history of the planet Earth, it was in 2008 and onwards that the urban population exceeds the rural residents (UN 2008). Rural individuals in many countries had been migrating towards urban areas in search of a better livelihood, job opportunities, education, and well-being (Bewket and Abebe 2013). This has led to the unplanned and rapid expansion of small cities creating enormous pressure on natural resources. There has been extensive deforestation in order to construct dwellings and houses for the people. Such fast-growing urban areas are becoming more and more congested creating urban slums. Urban slums again are becoming major sources of pollution of all kinds; air, water, and noise (Kapur 2016).

Current developments have also changed former urban settings towards more improvement with remarkable shifts in land use (Arsiso et al. 2018). Land use conversion into new urban settings, housing developments, office spaces, shopping centers, parking lots, complex road networks, industrial sites, etc., take away the naturally occurring lands that would provide habitat for the wildlife resources and other ecosystem functions. Such activities have significantly steered to the loss of millions of hectares of ordinary habitable environments (Woube 2005).

Though the rate of urbanization in Ethiopia is low (17\%) as compared with the African standard (40\%), it is said to be faster than what had been in the past times. However, in the last two decades, the growth rate was registered very fast in Ethiopia, while the rate largely declines in other African countries (Tegenu 2010). According to Moges and Bhat (2018), built-up lands in many places are more likely to share large agricultural land in the future. Urbanization in Ethiopia has always been related to 
remarkable environmental problems in almost all towns and emerging urban centers (Mpofu 2013). It demands intensive and extensive exploitation of natural resources such as a huge amount of fuelwood for energy consumption, large scale quarrying and excavation of sand, gravel, and other building materials as well as over-extraction and inefficient use of water resources. The cases in point are likely accelerating the degradation of the natural support systems and bring irreversible damage to ecosystem service provisions (Amera 2010). The impact is not only limited to the local environments but it also has large ecological footprint beyond its immediate locality. Generally, the fast pace of urban expansion has been liable for the reckless degradation of land, forest, and irrational use of other resources. In addition, conflicts could also arise among rural users over access to or control over such limited resources (Arsiso et al. 2018).

\section{Changing lifestyle}

There has been a remarkable change in the style of living among people across the world. Growing parts of the inhabitants are approaching a 'well to do' lifestyles. The changes are visible not only among the people living in cities and towns but also among those who live in rural villages. These sections of society are not easily satisfied with the benefactions of basic necessities (enough food, clothes, and housing) but are also impatient to obtain a quality life of high nutritious food, health care, comfortable living, and other quality amenities (Hubacek et al. 2007). This has enormously raised their level of resource consumption (Reusswig et al. 2003).

Specifically, the $20^{\text {th }}$-century lifestyle of the human population, with more advanced science and technology, had enormously threatened the sustainability of natural resources (Coria and Sterner 2011). In this century, human beings demand more comfortable living in terms of education, entertainment, recreation, transport, clothing, medication, and luxury shelter that claim the consumption of more resources and production of more goods and services. Accordingly, extra industrial processes were required definitely demanding more natural resources as raw material to produce more energy, food, fiber, and others required (Stavi and Lal 2015). Some of the processed resources again had produced hazardous wastes and harmful pollutants that damage the environment (Gil and Rico 2009).

This twenty-first century is even a vigorous century in which new scientific discoveries and new production methods are emerging frequently. The new technologies and advanced scientific methods have made possible massive extraction of desirable natural resources (Hao 2016). Hence, the maximum utilization of the resources and subsequent environmental pollutions do frequently exist (USAID 2006). In Ethiopia, where no pollution abatement mechanisms are well established, the problem is highly intensified and is causing cataclysmic damages.

\section{The notion of natural resources degradation}

Degradation of natural resource entails the deterioration of the environment through depletion of resources, destruction of ecosystems and extinction of biota (Gogoi 2013). It refers to any kind of modification or disruption to the environment that is supposed to be damaging or undesirable (Jouanjean et al. 2014).

The degradation of natural resources is not a new-fangled phenomenon; it had rather been happening everywhere in the world for centuries. The tricky is that the degradation is currently going on at a faster rate leaving no time for the environment to recover and regenerate. The greater demand required by an ever-increasing human population from the environment is putting excessive strain and drain on the earth's limited natural resources (Gogoi 2013; Pacheco et al. 2018).

\section{Extent and severity of natural resource degradation}

Natural Resources are the base of life on the planet earth. In doing so, resources are found to be the basis for human survival and development (Zhang 2018). Human beings could obtain and produce the materials they use in their day to day life from the natural resources. Every non-natural product is made either directly or indirectly from natural resources (Minale 2013). Naturally obtained materials may be used as it naturally occurs or after transformed into other forms. Therefore, most of the natural resources are likely to run down towards degradation, which has brought worldwide concerns for their sustainable usage and management (Gogoi 2013). Still, there are other few resources such as solar and wind energy providing continuous flow and stared to be inexhaustible. However, these resources are not sufficient enough for survival without using other exhaustible ones. The consequences of natural resource exploitation are clearly seen in soil erosion, loss of biodiversity, and pollution of land, air, and water bodies. As a result, environmental degradations from overexploitation of natural resources has reached a level of threatening human wellbeing and survival (Jouanjean et al. 2014).

\section{Land degradation}

According to FAO's framework for land evaluation (FAO 1981), land is a delineable area of the Earth's terrestrial surface which encompasses the physical environment including soil, spatial variability of landscape, climate, hydrology, vegetation and fauna, as well as land management practices and the influence potentials for land use. 
The United Nations Convention to Combat Desertification (UNCCD) defines land as "the terrestrial bio-productive system that comprises soil, vegetation, other biotas, and the ecological and hydrological processes that operate within the system" (UNCCD 2017). Land has also been considered as a platform on which most activities take place, the prerequisite for food and shelter, the natural repository for water and waste, and a major factor in the maintenance of breathable air (Long and Qu 2018). It is a crucial natural resource both for survival and prosperity and serves as the principal source of income for the farming community. Being a sole source of livelihood opportunities, it provides a sense of security to the community engaged in farming (Bedasa and Hussein 2018).

Land degradation refers to a process of soil degradation through water erosion and losses of vegetation cover leading to reduced productivity of the land in densely settled or exploitatively used regions (Nyssen et al. 2004). The UNCCD also forwarded a definition for land degradation as "a global environmental issue comprising the reduction or loss of land's biological or economic productivity against background thresholds of land deterioration and long-term loss of vegetation." Land degradation, therefore, is a process of land deterioration that includes a decline in the productivity of ecosystem goods and services obtained from land posing unlimited contests to both human and ecological systems (Nigussie et al. 2018). Accordingly, land degradation is the deterioration and persistent debility of the capacity of the land in supporting human and other life forms on Earth (Hurni et al. 2010; De Jong et al. 2011; Jamal et al. 2016). Generally, definitions regarding land degradation have been forwarded by different schools according to their interests (De Jong et al. 2011). However, almost all argued in that the term 'land' is shorthand for the system made up of soil, water, the biota together with the man-made landscape and their biophysical processes (Jaleta et al. 2016).

Land degradation occurs in all kinds of landscapes over the world. It is one of the serious global environmental issues increasing in severity and extent in different areas of the world (De Jong et al. 2011; Jamal et al. 2016). Land degradation is currently affecting about $40 \%$ of earth's surface, and another 12 million hectares to become degraded every year (Kapur 2016; Pacheco et al. 2018). Human dominance on earth's land and its natural resources have enormously amplified over the past century and have markedly changed the normal functioning of natural ecological processes on $75 \%$ of the land on Earth (UNCCD 2017). Latin America, Asia, and Africa are said to be the world's major soil degradation hotspots (Gessesse et al. 2015). In terms of land use types, over $20 \%$ of all cultivated areas, $30 \%$ of forests and $10 \%$ of grasslands are undergoing degradation. In actual facts, the degraded lands are homes for the most povertystricken rural population (Kapur 2016), and hence more than 2.6 billion people are presently facing the direct impact of land degradation in over a hundred countries (Gisladottir and Stocking 2005). The global cost of land degradation just looking to agriculture approaches US\$ 490 billion per year which is 3-6\% of the global agricultural Gross Domestic Product (GDP) (UNCCD 2015).

Land degradation is also a widespread problem in Ethiopia with over $85 \%$ of the land moderately to very severely degraded (Gashu and Muchie 2018), and about $75 \%$ affected by desertification (Gebreselassie et al. 2016). In the country, degradation of land stems from the historical development of agriculture and human settlement in the highland regions (Nyssen et al. 2015). Recent estimates using satellite imagery shows that land degradation hotspots over the last three decades cover about 23\% of the land area in the country, basically in large areas of Tigray, Wollo, and Gondar among others (Tesfa and Mekuriaw 2014).

\section{Soil erosion as a form of land degradation}

Soil erosion is the degradation of land that could occur through water and wind erosion (Hurni et al. 2016; Seifu and Elias 2018). Worldwide water erosion is accountable for $56 \%$ of land degradation followed by wind erosion causing $28 \%$. Water and wind erosion together are taking 75 billion tons of soil each year (at a rate of 17 tons per hectare ( $t / h a)$ in the USA and Europe; and 30-40 t/ ha in South America and Africa. However, the rate of soil formation amounts only 1-2 t/ha (Niemandt and Greve 2016). Land degradation attributable to soil erosion by running water is the most intimidating environmental problem in Ethiopia (Desta et al. 2000; Bewket and Abebe 2013; Amare and Belay 2015).

The major components of climate that affect soil erosion are rainfall and wind. Erosive processes are set in motion by the energy transmitted from either rainfall or wind or a combination of these forces (Tibebe and Bewket 2011). The rainfall power to produce erosion is related to rainfall amount, intensity, and distribution. However, rainfall intensity is more important than the rainfall amount in causing erosion (Yeshaneh et al. 2017). During rainfall, raindrops can easily dislodge soil particles, and more than one-half of it could be carried downhill on sloping lands. The high angle lands increased overland flow volume with the highest velocity loading more soil with it (Sisay et al. 2014). As a result, it is not surprising to hear that areas in various parts of northwestern, central and southeastern highlands of Ethiopian are suffering from the highest erosion rates every year (Gessesse et al. 2015; Hurni et al. 2016; Asfaw and Neka 2017). 
On the other side, the rate of wind erosion is determined by soil moisture content, surface soil roughness, wind velocity, vegetation cover and management practices like windbreaks (Nyssen et al. 2004). In this regard, wind erosion could be accelerated when soil becomes dry, weakly aggregated (less cohesive), and bare. Usually, when wind speed reaches $25 \mathrm{~m}$ per hour, the wind can detach and carry soil particles from unprotected soil. Even if the effects of erosion are not easily observed on a daily basis, water and wind are both capable of quickly damaging the soil (Taddese 2001). Throughout Ethiopia, sheet and rill erosions are by far the most widespread kinds of accelerated erosion affecting agricultural production more than other kinds of erosion. However, most significant present-day hydro-geomorphic processes are also taking place through gully formation in the highland parts, and wind-related erosion within Rift Valley area, and lowlands peripheries (Nyssen et al. 2004). Literally speaking, wind erosion in Ethiopia has not been measured nor clearly mentioned. In most of the cases, it is commonly occurring in the form of dust devils within areas continuously trampled by people or cattle including market places, footpaths, unsealed roads, and cattle drinking places.

Generally, the degradation of lands might be triggered by several processes that lower the potential productivity of land leading to long-term (sometimes irreversible) deterioration (Alemu 2017; Pacheco et al. 2018). Such processes are several but for this review we gave primary focus on the various processes of soil erosion related to biological, chemical (nutrient depletion), and physical degradation of soil. These processes are interlinked and may occur owing to natural causes but they are invariably enhanced by human intervention in the natural environment (Tefera and Sterk 2010).

Biological degradation of soil Biological degradation of the soil refers to the impairment that leads to a decline or elimination of the humus content (biomass carbon) of soil through mineralization and a decline in land bio-diversity (Jamal et al. 2016). The majority of organic matter is concentrated on the upper soil horizon in the form of decaying leaves, stems, and other organisms. The decomposition of these organic matters is a function of microbial activity (Haile et al. 2006). Consequently, erosion of topsoil results in a rapid decrease in soil organic matter causing a loss of food for soil microorganisms (Alemu 2017). Once soil organic matter is depleted, its productivity and crop yields are subject to decline as a result of nutrient loss and disturbed soil structure. Soil structure and the stability of soil aggregates are also dependent on microbial biomass. The removal of soil microorganisms either by erosion or burning causes physical damage to the soil ecosystem. These physical effects may, in turn, lead to increased erosion, organic matter depletion, and a further reduction in microbial activity (Bantider et al. 2011).

A decline in the organic matter has a long run and farreaching effect on both chemical and physical properties of soils. It affects soil physical properties through its influence on soil structure and aggregate stability which then influences soil erosion (Olson et al. 2016). Using dung for household fuel and crop residues for animal fodder are the most common practices in Ethiopia (Belay et al. 2015). It means denying the soil of its effective conditioner and fertilizer that help to add the necessary organic matter in it. This practice is most pronounced in densely populated areas of the country where forest cover has more or less disappeared and acute fuelwood shortage is being felt (Desta et al. 2000). In a nutshell, all factors that ultimately reduce the production and decay of soil organic matter will heighten the risk of biological degradation.

Chemical degradation (nutrient depletion) of soil Different soil nutrients are subject to be lost through erosion in runoff and eroded sediments (Seifu and Elias 2018). From the soil particles, the finer ones are the most vulnerable to erosion. Nutrients, being abundant in these finer soil fractions are also easily lost to erosion (Haile et al. 2006; Adimassu et al. 2014). Further nutrient losses occur through the deterioration of soil properties occurring due to acidification and salinization/sodification. Soil salinization is commonly occurring in dry and semi-dry areas where rainfall is insufficient to leach excess salts down through the soil profile (Stavi and Lal 2015). For instance, there are nearly 12 million hectares of salt-affected soils in eastern and southern Ethiopia. The main sources of salinity in these areas are shallow groundwater tables, natural saline seeps, and salts from marine origins (Taddese 2001). Conversely, acidic soils are most common in high rainfall areas (Endalew 2014). The process of acidification is intensified through burning and clearing of vegetation, continued use of acid-containing fertilizers, and excessive irrigation. Soil degradation due to acidification and salinity is increasing at a faster rate posing risk to the environment and agricultural ecosystems in various parts of Ethiopia (Richman et al. 2016).

In history, soil erosion has been a serious problem in various parts of the world (Tibebe and Bewket 2011; Yeshaneh et al. 2017) including Ethiopia (Hurni et al. 2010; Mekuriaw 2017; Abebe and Sewnet 2018; Wubie and Assen 2020). By and large, there is a greater concern about soil erosion in Ethiopia as it is supposed to be the major form of soil degradation and nutrient loss (Baye 2017). A study conducted in Amhara Region of Anjeni area revealed that the loss of nutrients from eroded soil 
in a 100 ha catchment area was about $210 \mathrm{~kg}$ Nitrogen, $680 \mathrm{~kg}$ Phosphorus, and $160 \mathrm{~kg}$ organic matter per hectare in a year, a relatively large amount (Desta et al. 2000). However, how much of those losses occurred owing to soil erosion, and what amount occurs attributable to chemical degradation is not yet clear. Concurrently, little is known about the nutrient loss processes existing throughout the country. As to Assefa and Hans-Rudolf (2017), the previous long-term monitoring in Ethiopian highlands indicated that high rates of soil loss resulted in a nutrient loss of at least $80 \mathrm{~kg}$ nitrogen, phosphors and potassium in one hectare each year. Generally, nutrient depletion can possibly be reduced by applying additional nutrients to croplands so as to replace potential losses through leaching, uptake by plants, and other related processes.

Physical degradation of soil Physical degradation of land may occur due to the sealing, compaction, debility in aeration, and decline of soil permeability (Haile et al. 2006; Sisay et al. 2014). Absence of organic matter and a high percentage of very fine sands and silt in soils are some of the factors contributing to surface sealing (Baye 2017). In Ethiopian farming practices, tillage operation for crop production requires repeated plowing of land with finely prepared seedbed using the most common instrument called 'maresha'. This farming tool affects soil structure, leaves the soil devoid of vegetation, and exposing it to easily detach by the action of the raindrops (Gessesse et al. 2015). In such cases, the clods dislodge and seal soil pore spaces. Reduction in soil pore spaces earnestly affect infiltration and escalate overland flow volume and velocity leading to soil crusting especially when it is dry (Nyssen et al. 2004).

The situation is even worse when it comes to sowing fine seeds like teff (Eragrostis tef) which demand fine seedbeds and cattle trampling to compact the soils for better germination and weed control. For instance, a teffseedbed preparation at Jimma (rainfall over $1500 \mathrm{~mm}$ per year) resulted in a soil loss of about $37 \mathrm{t} / \mathrm{ha}$ per year on a $9 \%$ slope which is four and half times higher than the tolerable level of soil erosion of a given field. In conclusion, the amount of tillage erosion mostly depends on the type of tillage practices, angle of slope, and resistance of the soil (Stavi and Lal 2015). Estimates suggested that between 15 and $600 \mathrm{t} / \mathrm{ha}$ of soil can be lost by tillage erosion annually in sloppy farmlands. However, tillage erosion hazard could be minimized by contour plowing and associated measures (Gessesse et al. 2015).

The other form of physical degradation of the soil is commonly taking place during overstocking in a limited grazing land. Overstocking and overgrazing including grazing of leftover residues on croplands after harvesting cause soil compaction due to heavy and continuous trampling by livestock (Haile et al. 2006). Watering points and cattle routes are particularly vulnerable to soil compaction, which leads to excessive runoff and reduced water infiltration. Revegetation in these areas is, therefore, obstructed (Bantider et al. 2011). Due to this, unimpeded water flowing down slopes causes rills and gullies which also make the damage more intense (Nyssen et al. 2004).

In conclusion, land degradation caused by soil erosion of any type (biological, chemical, physical, or other) is largely influenced by defects in soil management activities. Unsustainable management of land, livestock, and forest resources together with inefficient institutional and policy implements are considered as key factors for the problem (Desta et al. 2000). As indicated in Fig. 2, such causes are classified as direct or proximate causes, underlying causes, and policy arena. Production activity on marginal lands like steep slopes and fragile soils, limitation in adopting soil conservation measures, and inadequate investment to cover lands with vegetation augmented by erratic and erosive rainfall patterns, and other limitations of farming practices are among the proximate causes. Several factors underlying the direct causes are basically driven by population pressure, poverty, and associated socio-economic implications. Many of these factors will still be constrained by government policies and other non-governmental programs (Fig. 2).

\section{Process and drivers of land degradation}

Whether land degradation is mainly man-induced, natural, or both is a moot point (Evans and Geerken 2004). The focus of early researchers was on human-induced land degradation basically upon the impact of man on geology and ecology (De Jong et al. 2011). It was strongly emphasized that human-induced land degradation is becoming a serious global threat that escalate vulnerability contexts to the changing climate, specifically in areas of marginal agro-ecosystems with low and variable rainfall, steep slopes, and places with already degraded lands (Erkossa et al. 2018). More recently, fluctuating climatic conditions have been considered a significant cause (IPCC 2007). The change in view had brought about by the Sahelian droughts of the 1970s and 1980s, and the drying of Lake Chad (Barrow 2005). Since then, it was strongly believed that climatic variation is a significant factor influencing change in biodiversity within places like the arctic and boreal areas. On the other side, land use change is considered as the most important factor in other biomes (Turner II et al. 2007) (Fig. 3).

Many writers, however, agreed that various human and environmental processes interact along complex pathways and that both biophysical and socio-economic indicators should be considered jointly to trace the causes of 


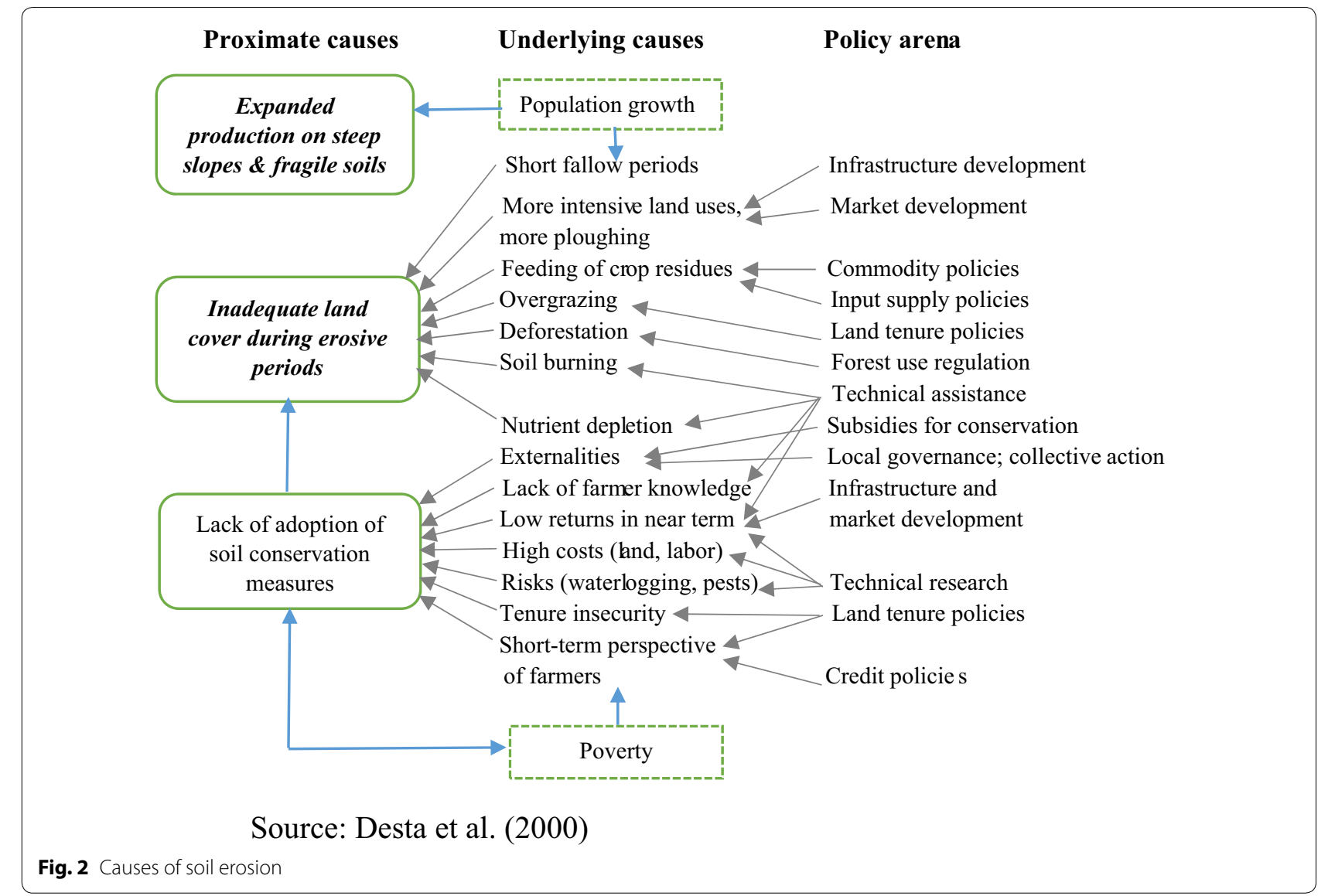

land degradation (Bewket and Abebe 2013; Sisay et al. 2014). The interaction of the human and the biophysical sub-systems on the land system is a continuous process. The biophysical sub-system interacts with the human sub-system by supplying environmental goods and services. However, this interaction might be diminished and/or ceased by land degradation depending on its extent (Turner II et al. 2007).

In Ethiopia, the intermingled action and reaction of high population growth, massive soil loss, deforestation, low vegetation coverage, unsustainable farming techniques, utilization of dung and crop residues for fuel, and overstocking of grazing lands are all considered as major drivers of land degradation (Tesfa and Mekuriaw 2014; Abebe and Sewnet 2018). According to the study of Vorovencii (2016), the major causes attributable to land degradation were further recapitulated towards diverse socio-economic adjustments, land ownership problems, marginalization, poverty, political instability, and recurrence of natural hazards. Another key driver of the problem is lack of capacity and/or commitment to address the problem appropriately (Angessa et al. 2019). Furthermore, small amount of investment in agriculture, poor rural infrastructure, modest markets, and the low level of technological advancement are cited as the ultimate causes of land degradation in Ethiopia (Yirdaw et al. 2017).

\section{Potential impacts of land degradation}

Biophysical and environmental consequences Land degradation has been a concern for many years in Ethiopia especially in the highland parts; areas above $1500 \mathrm{~m}$ altitude (Desta et al. 2000; Gessesse et al. 2015; Wubie and Assen 2020). This area covers more than $43 \%$ of the country, $95 \%$ of the cultivated area, $75 \%$ of the livestock and hosts about $88 \%$ of the population (Hurni et al. 2010). In addition, the highlands of Ethiopia are also places where most of the urban residents lived demanding more resources thereby greater degradation of land and other environmental resources (Arsiso et al. 2018). Although the extent of degradation varies from place to place, estimates show that about $50 \%$ of the highland areas have significant soil erosion where $25 \%$ of it was highly eroded and $4 \%$ seriously eroded beyond reclamation (Asfaw and Neka 2017). 


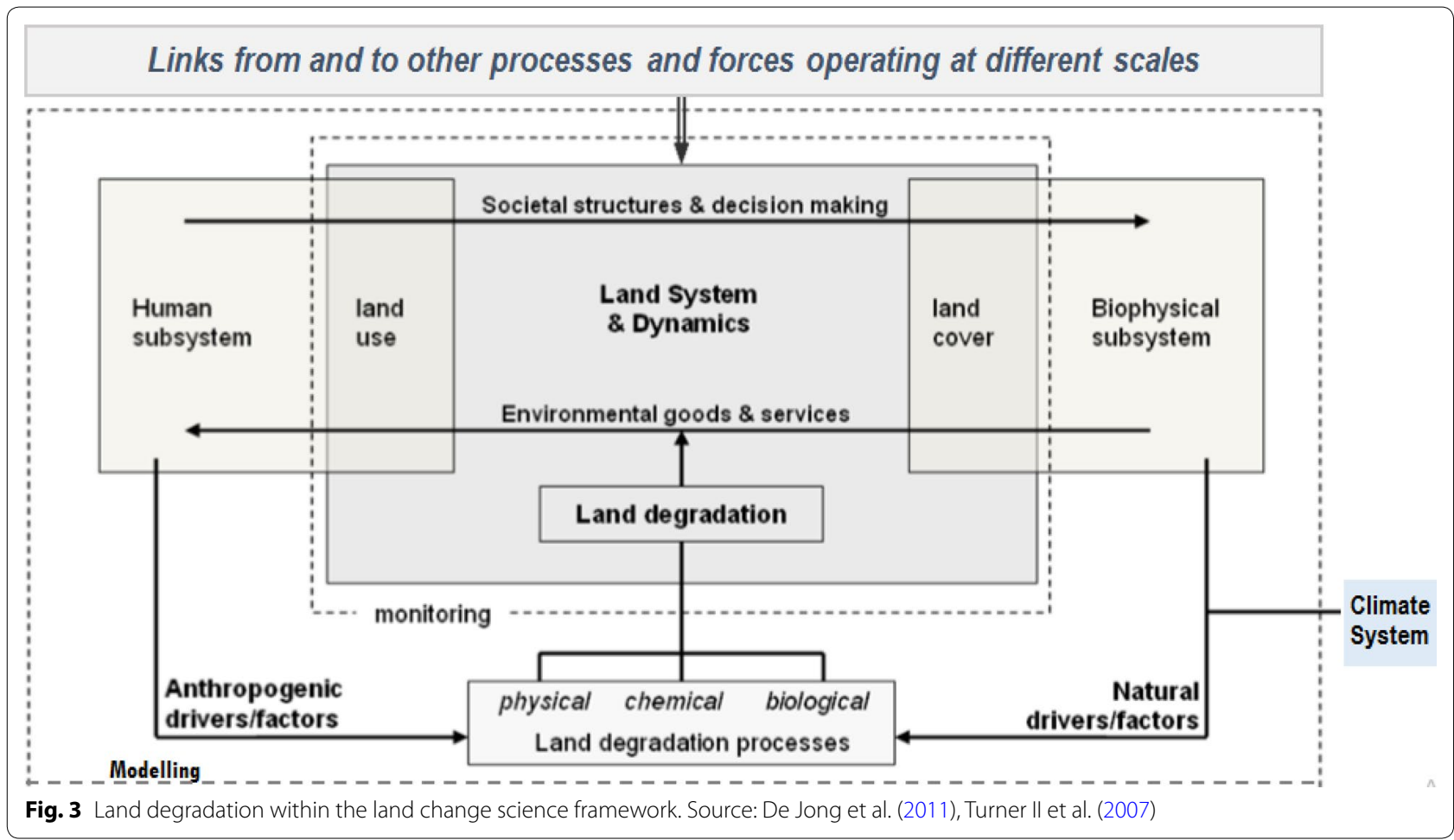

The findings of different studies from plot-level measurement supported by empirical models confirmed that soil erosion in the highlands of Ethiopian on average ranges from 37 to $300 \mathrm{t} /$ ha/year (Zeleke and Hurni 2001; Haile et al. 2006; Tefera and Sterk 2010; Tibebe and Bewket 2011; Haregeweyn et al. 2015; Gebreselassie et al. 2016). The tolerance limit of soil erosion in this part of the country ranges between 6 and $18 \mathrm{t} / \mathrm{ha} /$ year with an average estimation of $10 \mathrm{t} / \mathrm{ha}$ /year that actually show variation according to land use types (Hurni 1985). Assuming this rate as a limit for all types of land uses in the area, the rate of soil erosion is by far ( 5 to 16 times) higher than the average tolerable limits in the region, and has an incomparable difference as per the rate recommended for Ethiopia as a whole (1-6 t/ha) (Hurni 1983). It is, therefore, a great threat in this part of the country to bring the land improved in the future as it requires too much effort and resources (Taddese 2001; Wubie et al. 2016; Wubie and Assen 2020).

The rate of soil erosion is also high in other parts of the country. However, comparison of erosion rates within regions or places is difficult since rates of erosion obscure a high degree of variability in each area or a specific watershed over time (Gebreselassie et al. 2016). Such huge and continued soil losses everywhere in the country trigger people to put more pressure on the environment (Tolessa et al. 2017).
The environmental problems of land degradation are numerous including massive soil losses, the decline in water quality, biodiversity deterioration (Pacheco et al. 2018), and deprivation of ecosystem services and corresponding values for the present and future generations (Muleta et al. 2020). The changing climate will also drive certain types of land degradation through the action and inaction of more and sever extreme weather events augmented by a likely increase in areas affected by recurrent droughts. Simultaneously, land degradation interacts with atmospheric processes and may drive climatic change through increasing greenhouse gas emissions and reducing carbon fixation in soils and biomass (Erkossa et al. 2018).

\section{Impacts of land degradation on rural livelihoods and food} security Land degradation is a major cause of low and in most areas decreasing agricultural productivity, continuing food insecurity, and rural poverty in Ethiopia (Gashu and Muchie 2018; Pacheco et al. 2018). The direct consequence of land degradation is declining crop yields which eventually leads to a higher rate of poverty amongst the agrarian households. According to the UNCCD (2017) report, Ethiopia losses about 30,000 ha of agricultural land every year due to water erosion and over 2 million hectares are degraded each year. Based on experts' opinion, about $20 \%$ of the agricultural land in Ethiopia is subject to irreversible soil productivity loss due to water 
erosion. Each year, around 1 billion tons of topsoil is lost because of soil erosion alone where the situation is further aggravated by forest and livestock losses (Berry 2003).

Land degradation is widespread and has severe financial and social consequences and may sometimes be irrecoverable on a human time scale at manageable cost (Sisay et al. 2014). Several studies offer numerical estimates on the expenses incurred owing to land degradation. Teketay (2001) in his study estimated that the reduction in the depth of the soil due to erosion caused a grain production loss of 57,000 (at $3.5 \mathrm{~mm}$ soil loss) to 128,000 tons (at $8 \mathrm{~mm}$ soil depth) in the year 1990 alone. Grain production loss due to land degradation in that particular year was estimated to have been sufficient to feed more than four million people. Similarly, Berry (2003) estimated that degradation of land, and other nonsupportive land management practices cost the country (via loss of soil and essential nutrients) about 3\% of the agricultural GDP or \$106 million in the year 1994. On the whole, the annual cost of land degradation is about $\$ 4.3$ billion in Ethiopia, representing 22.5\% of the GDP (Gebreselassie and Kirui 2015). While modeling the impact of water erosion on food production in Ethiopia, Sonneveld (2002) estimated a range of potential reductions in the production of $10-30 \%$ by the year 2030 .

The most serious on-site consequence of soil erosion to the farming community is a failure in both the current and potential crop and livestock yields that transform into losses of income. Soil erosion impacts may also be viewed in prompting farmers need to apply more inputs in their farmlands to maintain soil productivity; and hence, subject them for more expense in the process of attaining soil fertility for better yield (Gebreselassie et al. 2016). Soil erosion from farming plots has also serious external/off-site impacts having an indirect effect on society. Such effects are instigated by the siltation of hydroelectric dams, pollution of municipal water reservoirs, ponds, etc. For example, the hydroelectric power generation capacity of the Koka dam, one of the old dams in Ethiopia, is highly affected by silt deposition. According to current estimates, around 30\% of the total storage volume of the reservoir has already been lost to sedimentation, which obviously had undesirable impact on the annual hydroelectric power generation (Eyasu 2003). Furthermore, the effect of land use changes like expansion of the agricultural frontier and the migration of people towards pastoral lands, and surrounding fragile ecosystems could also be considered as the other form of off-site impacts of soil erosion (Tolessa et al. 2017).

Land degradation could be averted by applying different mechanisms contingent with the nature, form, and extent of the degradations. It can be prevented or reversed by adding key nutrients to the depleted soil, rebuilding topsoil through soil amendments, re-establishing vegetation cover, buffering soil acidity, or applying other physical management mechanisms (Endalew 2014). Nonetheless, some aspects of land degradation may not be easily reversed. For example, total loss of topsoil by erosion, or terrain deformation by gully erosion, or the wiping out of native soil fauna are largely irreversible than simple nutrient losses, or surface sealing and crusting (Tesfa and Mekuriaw 2014; Niemandt and Greve 2016).

\section{Degradation of water resources}

The geographic location of Ethiopia, its physical topography, and the favorable climate provide a relatively higher rainfall amount in the area (Mekuriaw and Hurni 2015). It receives an average of $1090 \mathrm{~mm}$ total annual rainfall every year (Awulachew and Yilma 2008). There are about 12 basins throughout the country where 8 of which are river basins, 1 lake basin, and the remaining 3 dry basins with no or insignificant flow outside the drainage basin (Berhanu et al. 2014). River-basin surveys show that the aggregate annual surface runoff in Ethiopia from the 12 basins is close to 122 billion cubic meters $\left(\mathrm{BM}^{3}\right)$ excluding groundwater (Table 2). Within these basins, the country is endowed with fresh lakes (11), saline lakes (9), crater lakes (4), and more than 12 major wetlands. Lake water in Ethiopia amounts around $70 \mathrm{BM}^{3}$ where the majority of these lakes are located within the Rift Valley (Berhanu et al. 2014). On the other hand, the total area covered by wetlands in Ethiopia is nearly 2\% (22,600 $\mathrm{km}^{2}$ ). Though a small coverage with scattered distribution, it could offer desirable resources and ecosystem services used as a source of food, tourism, flood regulation, waste treatment, and water quality improvement along with the conservation of biodiversity and wildlife (Bezabih and Mosissa 2017).

Much of the surface water in Ethiopia, however, flows towards the neighboring countries by the trans-boundary rivers (Awulachew et al. 2007). Usually, the annual amount of available water resources in Ethiopia give the wrong impression that 'rainfall is said to be adequate for crop production'. Due to the variations of rainfall (both spatial and temporal) and lack of infrastructure, there is no enough pure drinking and irrigable water for most farmers in Ethiopia to make them capable to produce a crop at least twice a year (Awulachew and Yilma 2008).

Ethiopia's water resource problem is largely tied with its uneven distribution and the variation in spatial and temporal occurrence. Around $80-90 \%$ of the water resource in the country is accumulated only in the 4 major river basins such as Abay (Blue Nile), Tekeze, Baro-Akobo, and Omo-Gibe in the west and South-western part of Ethiopia where the population is not more than 30 to $40 \%$. 
Table 2 River basins and their irrigation and hydropower potential in Ethiopia

\begin{tabular}{|c|c|c|c|c|c|c|}
\hline River basin & $\begin{array}{l}\text { Catchment area } \\
\left(\mathrm{km}^{2}\right)\end{array}$ & $\begin{array}{l}\text { Annual Runoff } \\
\left(\mathrm{BM}^{3}\right)\end{array}$ & $\begin{array}{l}\text { Specific } \\
\text { discharge } \\
\left(1 / \mathrm{s} / \mathrm{km}^{2}\right)\end{array}$ & $\begin{array}{l}\text { Potential irrigable } \\
\text { land (ha) }\end{array}$ & $\begin{array}{l}\text { Gross hydroelectric } \\
\text { potential (Gwh/year) }\end{array}$ & $\begin{array}{l}\text { Estimated ground } \\
\text { water potential } \\
\left(\mathrm{BM}^{3}\right)\end{array}$ \\
\hline Abbay & 199,812 & 52.6 & 7.8 & 815,581 & 78,820 & 1.80 \\
\hline Awash & 112,700 & 4.9 & 1.4 & 134,121 & 4470 & 0.14 \\
\hline Baro-Akobo & 75,912 & 23.6 & 9.7 & $1,019,523$ & 13,765 & 0.28 \\
\hline Genale-Dawa & 171,042 & 5.88 & 1.2 & $1,074,720$ & 9270 & 0.14 \\
\hline Mereb & 5,900 & 0.65 & 3.2 & 67,560 & - & 0.05 \\
\hline Omo-Ghibe & 79,000 & 16.6 & 6.7 & 67,928 & 36,560 & 0.42 \\
\hline Rift Valley & 52,739 & 5.6 & 3.4 & 139,300 & 800 & 0.10 \\
\hline Tekeze & 82,350 & 8.2 & 3.2 & 83,368 & 5980 & 0.20 \\
\hline Wabe-Shebele & 202,697 & 3.16 & 0.5 & 237,905 & 5440 & 0.07 \\
\hline Afar-Denakil & 74,002 & 0.86 & - & 158,776 & - & - \\
\hline Ogaden & 77,121 & - & - & & - & - \\
\hline Aysha & 2,223 & - & - & & - & - \\
\hline Total & $1,135,498$ & 122.05 & & $3,798,782$ & 155,102 & 3.20 \\
\hline
\end{tabular}

Source: Compiled from Awulachew et al. (2007) and MoWR (2002)

Conversely, the water resource available in the east and central river basins are only 10 to $20 \%$ whereas the population in these basins is over 60\% (MoWR 2002).

Besides, Ethiopia is endowed with many small streams and springs which can potentially be utilized for water harvesting during the rainy and dry seasons. Ethiopia has also a groundwater resource but the true potential of the country is not yet known (NMSA 2001). Although it is required to make a detailed investigation, currently, it is widely reported that the groundwater potential of the country reaches around $40 \mathrm{BM}^{3}$ (Mengistu et al. 2019). Therefore, if one considers the current 100 million population of Ethiopia (Beyene 2015), the totally available $162 \mathrm{BM}^{3}$ surface and groundwater resource of the country makes an average of 1620 cubic meters of physically available water per person per year, which is comparatively a large volume.

In terms of water consumption, a very small proportion of water resource is used (Awulachew and Yilma 2008) all over the country. For instance, only $1 \%$ of the estimated annual surface water of the $122 \mathrm{BM}^{3}$ is used for irrigation and hydropower generation yet. The irrigation potential of Ethiopia is estimated to be three to four million hectares not including the underground water and water harvesting. However, the area of land under irrigation so far is only $3 \%$ showing that water resources have made a little contribution to the development of irrigated agriculture till now (NMSA 2001). Many field studies disclosed that Ethiopia is endowed with the highest potential in hydropower generation next to Democratic Republic Congo. The mountainous landscape and its hydrological feature make the country capable to generate hydroelectric power at a minimum cost (Awulachew and Yilma 2008). So far, however, only a very small amount of this huge potential is utilized in the country. If Ethiopia develops hydropower generation well, it can afford to supply surplus power enough to be marketed to the neighboring nation-states earning adequate foreign exchange beyond meeting the national energy demand (NMSA 2001).

Clean freshwater resources are needed for household utilities (drinking, cooking, bathing, etc.), irrigation agriculture, industrial process, and plant and animal survival (Alelign 2016). However, chronic potable water shortage is found to be a common problem in various parts of Ethiopia. The problem is very serious in rural parts of the country. Due to this, Ethiopia is listed in the frontline among countries having very low pure water supply and coverage levels at least by Sub-Saharan African standards. Most of the sources supplying freshwater such as groundwater, reservoirs, rivers, and streams are subject to excessive and intensified environmental pressure due to excessive use, contamination, ecosystem degradation, and climate change (MoWR 2002).

Climate change and inefficient use of water resources are posing severe consequences both on water quality and availability, especially in drylands (Marques et al. 2016). According to Awulachew et al. (2007) report, the absence of comprehensive water resources management policy in Ethiopia has so far caused negative impacts on the advancement of water resources. Among such problems, the prominent ones are nonexistence of sustainable and consistent water resource management policy, and difficulties related to effective use of water resources. 
Similarly, the prevalence of unrealistic, unattainable, and non-objective oriented plans, programs, and project implementations as well as shortfall in maneuver and maintenance accomplishments of water schemes, and weakness in institutional sustainability are found to be the major defects.

Generally, excessive exploitation and pollution from different sources are exceedingly damaging the surface and groundwater supplies than the other factors in Ethiopia. The source of pollution can be from industry, sewage or livestock waste, and agrochemicals. As stated earlier, the poorly managed soil and continuously altered vegetation cover leads to diminished and contaminated water supplies that intensified water resource degradation throughout Ethiopia. When water resources are subject to degradation, the other land resources (vegetation, soils, terrain, and climate) alongside the associated various socio-economic activities, particularly in the farming sector are also affected in a trend vicious circle.

\section{Degradation of forest resources The status of forests in Ethiopia}

Forests are one of the vegetation biome dominantly covered by trees of different species that inhabit several biotic lives (Pistorius et al. 2017; Mekonnen et al. 2018). Land spanning more than 0.5 ha with trees higher than $5 \mathrm{~m}$ and a canopy cover of more than $10 \%$ can be called a forest (FAO 2010). In the Ethiopian context, as Mekonnen et al. (2018) stated, "forest is an area with natural mosaics, dense agroforestry, acacia woodlands and shrub lands, state and private plantations of about a timad or more (timad is local land area measurement $\approx 0.25 \mathrm{ha}$ )." Hence, forest resources may be those which exist naturally or made by man through plantation (Danano et al. 2018).

Historical sources revealed that the Ethiopian highlands had a much greater forest and woodland cover (90\% coverage) in the past while its lowland areas were covered with shrubs and bushes (Mekuriaw and Hurni 2015; Abebe and Sewnet 2018). There has been continuous deforestation throughout the past 3000 years that enormously accelerated during the last century (Bishaw 2009). The country has experienced a much rapid decline in its forest cover and a serious deterioration of its land quality over the past decades (Kassa et al. 2016; Gashaw et al. 2018). The allegedly thick forest cover had been destroyed on account of ever-growing demands for firewood, construction wood log, pasturelands, farm implements, and for crop production to accommodate the fast-growing population (Danano et al. 2018). In such instances, forest areas of the country have been reduced from $35-40 \%$ ( $66 \%$ when savanna woodlands are included) a century ago to an estimated $16 \%$ by the early
Table 3 Natural forest vegetation coverage of Ethiopia in 1990

\begin{tabular}{lll}
\hline Vegetation type & $\begin{array}{l}\text { Area } \\
\text { (Million ha) }\end{array}$ & $\begin{array}{l}\text { Percent } \\
\text { coverage } \\
\text { (\%) }\end{array}$ \\
\hline High forest & 3.44 & 2.8 \\
Reverain and Mangrove & 1.3 & 1.1 \\
Bamboo Woodlands & 0.45 & 0.4 \\
Mixed Deciduous & 2.5 & 2 \\
Acacia-Boswellia and Wooded & 20 & 16 \\
Grasslands & 27.69 & 22.3 \\
Sub total & 92.31 & 77.7 \\
Other lands & 120 & 100 \\
Total & &
\end{tabular}

Source: Bishaw (2009)

1950 s, $3.6 \%$ in the early 1980 s, and only $2.7 \%$ by the year 1989 (Teketay 2001; Bishaw 2009).

The distribution of forests and other vegetation covers in Ethiopia was further estimated based on the information from LANDSAT imagery analysis (Table 3). According to Bishaw (2009), the 1991 Ministry of Agriculture (MoA) report of the time revealed that $2.8 \%$ of the land surface was under forest. In Ethiopia, the highland forests are broadly classified into two, dry and moist montane forests. The dry montane forests are dominated by hard leaved evergreens whilst moist montane forests account for enormous broad-leaved and soft-leaved tree species (Bishaw 2009).

The amount of forest resource coverage in Ethiopia has been studied by different bodies like FAO, Ethiopian Forestry Action Program (EFAP), Woody Biomass Inventory and Strategic Planning Project (WBISPP), etc., and individual reports including (Reusing 1998) at different time periods. Table 4 below shows the detail of the forest account in Ethiopia up to the year 2005.

In Ethiopia, there exist inter-regional variations in the amount of forest resource coverage. According to the World Bank-funded WBISPP, variation in the forest, woodlands, and shrub lands coverage depends on regional states' size, climate, and history of human settlement in the areas (WBISPP 2004). According to the report (Table 5), Oromiya accounts the highest share which holds around $62.5 \%$ of the high forest coverage in the country. It also occupied high woodland coverage (34\%) next to the Somali Regional State, and the highest (29\%) coverage in woodlands than any other Regional States in the country. On the other hand, Harari and Dire Dawa holds a very small amount of forest and other woody vegetation coverage as they have very small rural areas. 
Table 4 Forest resource statistics in Ethiopia reported by different sources

\begin{tabular}{|c|c|c|c|c|c|c|c|}
\hline \multirow[t]{2}{*}{ Forest resource } & \multicolumn{2}{|c|}{ EFAP, 1994} & \multirow{2}{*}{$\begin{array}{l}\text { Reusing, } 1998 \\
\text { Area } \\
\text { (million ha) }\end{array}$} & \multirow{2}{*}{$\begin{array}{l}\text { FAO, } 2001 \\
\text { Area (million ha) }\end{array}$} & \multirow{2}{*}{$\begin{array}{l}\text { WBISPP, } 2004 \\
\text { Area (million ha) }\end{array}$} & \multicolumn{2}{|l|}{ FAO, 2005} \\
\hline & $\begin{array}{l}\text { Area } \\
\text { (million } \\
\text { ha) }\end{array}$ & $\begin{array}{l}\text { Growth } \\
\text { stock }\left(\mathrm{m}^{3} /\right. \\
\text { ha) }\end{array}$ & & & & Area (million ha) & Stock $\left(\mathrm{m}^{3} / \mathrm{ha}\right)$ \\
\hline Natural high forest & 2.3 & & 5.755 & 4.506 & 4.072 & 12.509 & 22 \\
\hline Slightly disturbed forest & 0.7 & $90-120$ & 1.680 & 0.235 & & - & \\
\hline Highly disturbed forest & 1.6 & $30-100$ & 4.075 & 4.271 & & 12.509 & 22 \\
\hline Woodlands & 5.0 & $10-50$ & $31.554^{* *}$ & & 29.24 & 44.650 & 2.3 \\
\hline Bushlands & 20.0 & $5-30$ & & & 26.40 & & \\
\hline Plantations* & 0.2 & & 0.216 & & 0.216 & 0.419 & 22 \\
\hline Farm forests & NA & NA & NA & & NA & NA & NA \\
\hline $\begin{array}{l}\text { Relative reliability rank- } \\
\text { ing of the sources }\end{array}$ & 3 & & 4 & 2 & 1 & 4 & \\
\hline
\end{tabular}

Source: Lemenih and Woldemariam (2010)

* FAO statistics on plantations (only commercial), ** woodlands and bushlands combined; NA= data not available

Table 5 Forest distribution in Ethiopia by Region, according to WBISPP 2004

\begin{tabular}{|c|c|c|c|c|c|c|}
\hline \multirow[t]{2}{*}{ Region } & \multicolumn{2}{|c|}{ High Forest } & \multicolumn{2}{|l|}{ Woodlands } & \multicolumn{2}{|c|}{ Shrub lands } \\
\hline & Total (ha) & $\%$ total & Total (ha) & $\%$ total & Total (ha) & $\%$ total \\
\hline Oromiya & $2,547,632$ & 62.5 & $9,823,163$ & 34 & $7,750,422$ & 29 \\
\hline SNNP & 775,393 & 19.0 & $1,387,759$ & 5 & $2,434,779$ & 9 \\
\hline Gambella & 535,948 & 13.2 & 861,126 & 3 & 146,103 & 1 \\
\hline Amhara & 92,744 & 2.3 & $1,040,064$ & 4 & $4,352,672$ & 17 \\
\hline Beneshangul-Gumuz & 68,495 & 1.7 & $2,473,064$ & 8 & $1,422,191$ & 5 \\
\hline Tigray & 9,332 & 0.2 & 294,455 & 1 & $1,841,182$ & 7 \\
\hline Afar & 39,197 & 1.0 & 163,657 & 1 & $3,021,697$ & 12 \\
\hline Somali & 4,257 & 0.1 & $13,199,662$ & 45 & $5,384,022$ & 20 \\
\hline Others (Harari, Dire Dawa) & 216 & 0.0 & 0 & 0 & 44,13 & 0 \\
\hline Total & $4,073,214$ & 100 & $29,242,950$ & 100 & $26,400,200$ & 100 \\
\hline
\end{tabular}

Source: WBISPP (2004)

The latest Global Forest Resource Assessment made for Ethiopia based on several data sources reported that the area of forest and other wooded lands has increased by 0.3\% for the period 2010-2015 (FAO 2015). According to the FAO definition of "forest" (which includes forest, high woodlands, and plantations), the current area of forest coverage in Ethiopia is around 12,499,000 ha; which is $11.4 \%$ of the total land area. This is partly ascribed to growth in tree plantations in a number of places in the country. However, elsewhere in the country's report, deforestation since 2010 is likely to reach $1.25 \%$ per annum (Muleta et al. 2020).

The remaining natural forest-covered areas in Ethiopia are largely located at southern and southwestern sections of the country. In these areas, the high forests have been identified and subsequent efforts are being made to conserve, protect, and manage them on basis of sustained yield. Currently, however, available high forest areas are wide-open to a number of development project pressures, like coffee and tea plantations, human resettlement, grazing, and logging maneuvers (Abera et al. 2020). Owing to the immediate importance of such operations, but with long-term impacts, efforts have been made to identify the remaining high forests within 57 National Forest Priority Areas (NFPA). These areas cover about 3.44 million hectares $(2.8 \%)$ of the country at that time (Table 3). However, the protection and management mechanisms of NFPA is questionable even today because of the unclear and inefficient forest policy.

Forest resources are playing vital roles in supporting the livelihoods of the world's poor, particularly in meeting their daily subsistence needs (Siraj et al. 2016). Accordingly, forests and the benefits it offers in the form of food, wood, fiber, income, and environmental protection play 
a critical role in making people capable to secure stable and adequate food supply. Therefore, forests can diversify livelihood opportunities for the local population and help to maintain food security (Marques et al. 2016).

Apart from the wood supply, Ethiopia's forest resource provides a large amount of different non-tree forest products. Among which, the most important ones are forest coffee, gum and incense, and honey and wax (Lemenih and Woldemariam 2010). For instance, about 30-35\% of the annual coffee production in Ethiopia is obtained directly from either wild or semi-managed coffee forests (Wakjira 2006). About 4107 tons of gums and resins are also harvested every year from the woodlands (Lemenih 2009). In terms of medicinal value, about 1000 indigenous plant species in Ethiopia (the majority of which wild plants), have been notified to have herbal medicinal applications. From these, over 56,000 tons of medicinal plants are collected and used every year where the majority are harvested from wild plant stocks (Lemenih and Woldemariam 2010) (Table 6).

According to Yemiru et al. (2010), forest products in areas around Bale Mountain were found to be important sources of income for the local population contributing to $34 \%$ of household per capita income and about $53 \%$ of its per capita cash income. Similarly, primary forests are an important provider of biodiversity that can be linked to various economic activities, from the provision of medicinal products to tourism. It also provides ecosystem services, climate change mitigation and adaptation, pollution abatement (Jouanjean et al. 2014; Siraj et al. 2016) as well as protection and enforcement of natural capital (Mbow et al. 2014).

Deforestation and land degradation, however, is weakening the capacity of forests by making them deliver a reduced supply of goods and services from the given site (Bishaw 2009; FAO 2011). Therefore, forest degradation could have an impact on populations' livelihoods and income generation activities through the reduction and loss of direct economic services (Muleta et al. 2020). In addition, it could also have an indirect impact through the loss of ecosystems and environmental provisioning services (Dejene 2003; Jouanjean et al. 2014).

\section{Potential causes and consequences of forest degradation}

The term 'forest degradation' refers to a reduction in the capacity of a forest to provide expected goods and services (FAO 2011). Deforestation or forest degradation in Ethiopia takes a lead among the major problems that forest resources are encountered. Such degradations are done mainly for fuelwood and agricultural expansion (Birhanu 2014; Kassa et al. 2016; Alemu 2017; Assefa and Hans-Rudolf 2017). The rate of deforestation has been increasing year after year with an estimated average of 160,000-200,000 ha/year. In such estimations, fertile topsoil has been continuously lost at a rate larger than $1 \mathrm{BM}^{3}$ each year. This, in turn, results in massive environmental degradation and constitutes a serious threat to the sustainability of agriculture and forestry (Bishaw 2009).

Similar to the problem of availability for forest statistics, there is also a lack of reliable sources of data on the amount and rates of forest degradation and/or deforestation in Ethiopia. However, many historical sources are evident for deforestation which has been taking place for thousands of years (Nyssen et al. 2004). Foresters, on the other hand, argued that the rate of deforestation has been highly accelerated within the last 150 years largely driven by the high population growth (Reusing 1998). Hence, Ethiopia had lost and is continuing to lose much of its forests and other natural vegetation resources with no substantial efforts to reverse the trend. The general situation of deforestation in the country is summarized by FAO (2005).

One of the earliest report compiled by Reusing (1998) designated a $1 \%$ deforestation rate every year within the years 1986 to 1990 all over the country (163,600 woody plants/ha/year). Similarly, the report of FAO (2005) also indicated a deforestation rate of $0.93-1.04 \%$ per year between the years 1990 to 2005. WBISPP (2004) again analyzed the rates of deforestation in areas where some natural high forests are still existing. It predicted a loss of 1.33 million hectares between the years 1990 and in 2020. This loss is equivalent to over $1 \%$ annual forest resource decline in the country. Various studies conducted in different localities of the country within different time periods reported that disparity in the amount

Table 6 Changes in Ethiopia's forest resources from 1990 to 2005

\begin{tabular}{|c|c|c|c|c|c|c|c|}
\hline \multicolumn{5}{|l|}{ Forest } & \multirow{2}{*}{\multicolumn{3}{|c|}{$\begin{array}{l}\text { Other land with woody biomass } \\
\text { Area } \times 1000 \text { ha }\end{array}$}} \\
\hline \multicolumn{3}{|c|}{ Area $\times 1000$} & \multicolumn{2}{|c|}{ Annual change rate $\times 1000$ ha } & & & \\
\hline 1990 & 2000 & 2005 & $\begin{array}{l}1990-2000 \\
‘ 000 \text { ha/yr } \\
(\%)\end{array}$ & $\begin{array}{l}2000-2005 \\
‘ 000 \mathrm{ha} / \mathrm{yr} \\
(\%)\end{array}$ & 1990 & 2000 & 2005 \\
\hline 15,114 & 13,705 & 13,000 & $\begin{array}{l}-141 \\
(-1.0)\end{array}$ & $\begin{array}{l}-141 \\
(-1.1)\end{array}$ & 44,650 & 44,650 & 44,650 \\
\hline
\end{tabular}

Source: FAO (2005) 
Table 7 Study reports on deforestation rates in different parts of Ethiopia

\begin{tabular}{|c|c|c|c|c|}
\hline Local area under vegetation cover & Study years & $\begin{array}{l}\text { Forest cover } \\
\text { decline (\%) }\end{array}$ & $\%$ change year $^{-1}$ & Source \\
\hline South Wollo & 1958-1986 & $30.6 \& 51^{*}$ & $1.1 \& 1.8^{*}$ & Tekle and Hedlund (2000) \\
\hline Northwestern Ethiopian Highlands & 1957-1995 & 98.9 & 2.6 & Zeleke and Hurni (2001) \\
\hline Awassa watershed & $1972-2000$ & 82 & 2.9 & Dessie and Kleman (2007) \\
\hline Northern Afar ranglands & 1972-2007 & $89.9^{* *}$ & 2.6 & Tsegaye et al. (2010) \\
\hline Gish Abay watershed & $1957-2001$ & 64 & 1.5 & Bewket and Abebe (2013) \\
\hline Eastern Ethiopia highlands & $1985-2011$ & $63.4^{*}$ & 2.4 & Meshesha et al. (2014) \\
\hline Central rift valley area & 1973-2014 & 56.6 & 1.4 & Ariti et al. (2015) \\
\hline Gumara watershed, Lake Tana basin & $1957-2005$ & $85.3 \& 91.4^{*}$ & $1.8 \& 1.9^{*}$ & Wubie et al. (2016) \\
\hline Libokemkem District, South Gonder & 1973-2015 & 82.2 & 1.9 & Demissie et al. (2017) \\
\hline Andassa watershed, Blue Nile Basin & $1985-2015$ & 45 & 1.6 & Gashaw et al. (2017) \\
\hline Gelda catchment, North Western Ethiopia & $1957-2014$ & 83.8 & 1.5 & Hassen and Assen (2017) \\
\hline South Western Ethiopia & $1987-2015$ & 54.4 & 1.9 & Danano et al. (2018) \\
\hline Muga watershed, Upper Blue Nile basin & $1985-2017$ & $21 \& 12^{*}$ & $0.7 \& 0.4^{*}$ & Belay and Mengistu (2019) \\
\hline Central highlands of Ethiopia & $1957-2017$ & 37.8 & 0.6 & Deribew and Dalacho (2019) \\
\hline Komto protected forest East Wollega Zone & $1991-2019$ & 37.4 & 1.3 & Negassa et al. (2020) \\
\hline Lake Ziway watershed & 1973-2018 & $76.4^{* *}$ & 1.7 & Desta and Fetene (2020) \\
\hline
\end{tabular}

* Shrub lands (areas covered with small trees, bushes and shrubs which are less dense than forests)

** Woodlands (areas covered by woody plants mainly acacia-dominated species)

of forest degradation does exist. In Table 7 below, one can find some of the studies conducted for land use land cover change detections in the common land use types in Ethiopia including lands covered by forest. From such analysis, forest coverage has shown a decline by the rate from the maximum $2.9 \%$ to the minimum $0.6 \%$ in each study years. By merging all these studies, it can be shown that Ethiopia has been lost on average a $1.6 \%$ of its woody biomass annually through deforestation.

There are several causative factors for large scale deforestation in Ethiopia (Tolessa et al. 2019). The ever-present poverty and rapid population growth are considered as the main causes fueling the rate of deforestation to intensify, and forest degradation to worsen in Ethiopia (Lemenih and Woldemariam 2010). Rapid population growth has not only led to land clearance for agricultural purposes, but also to overgrazing in a dominant mixed cereal-livestock production system. It also urges increased pressure on existing forests because of the increasing demand for fodder, fuelwood, and building materials (Kassa et al. 2009). At a national level, biomass energy offers over $99 \%$ of the total domestic energy consumption (92\% for households and the remaining being consumed by small-scale industry and food enterprises). From this, about $78 \%$ is derived from woody biomass, whereas around 12 and 9\% are from animal dung and crop residue respectively (Nune et al. 2013).

Forest resources are also used as cash income sources through selling wood log, fuelwood, and charcoal. During the last 50 years, charcoal production increased from one million tons to more than three million tons each year. Within this time period, fuelwood consumption also increased from 40 to 100 million cubic meters in a year (Asfaw and Demissie 2012). These all had been done at the expense of forests. Encroachment of farmland and pasture into the natural forests had also been a common practice in many parts of Ethiopia. Such deforestation activities and overgrazing have led to soil erosion resulting in land quality deterioration, biodiversity loss, and impact on the overall climate system posing a serious problem in every aspect of human life (Jouanjean et al. 2014; Kassa et al. 2016).

\section{Degradation of wildlife resources}

Wildlife is a term which plainly refers to animals not normally domesticated. Nonetheless, wildlife embraces all living organisms (except people) that are not domesticated and found in the wild. Wildlife, thus, refers to the varieties of all living organisms inhabiting in the wild at the species, genetic, and ecosystem levels on the planet earth (Amare 2015a).

According to the report from the Ethiopian Biodiversity Institute (EBI), Ethiopia is endowed with a large variety of native plant and animal species within its diverse climate and topography (EBI 2014). Currently, around 320 species of mammals including 39 endemics, 918 species birds with 19 endemics, 240 species reptiles (16 endemics), 71 species amphibians (30 endemics) and 172 
species freshwater fishes with 38 endemics and more than 1225 species of insects are scientifically recorded in Ethiopia (Teketay 2001; EBI 2014; Amare 2015a). As a result, Ethiopia is among few countries with the most diverse mammalian faunas in Africa and blessed with the great attractions of its wildlife heritage. Similarly, the country is also endowed with floral diversity with more than 6500 species of vascular plants (with 625 endemic and 669 near-endemic species, and one endemic plant Genus). So, it is ranked as the fifth-largest floral country in tropical Africa (Birhan and Gebreyes 2015).

There are different National parks, wildlife reserves, and sanctuaries in the country used to manage and protect wildlife resources. They are referred to as principal conservation areas which cover approximately $2.9 \%$ of the country's surface area (Birhan and Gebreyes 2015). Currently, Ethiopia's protected areas are more than 55 in number. It includes 22 national parks, 19 controlled hunting areas, 10 open hunting areas, 3 wildlife sanctuaries, and 2 wildlife reserves. So far, the Simian Mountains and Gambella national parks are gazettes notified, while the others listed together with the national forest priority areas are not gazettes notified (Marino 2003). Hence, many of the protected areas in the country are closely hemmed-in and largely exploited by the nearby agrarian and pastoralist communities (Birhan and Gebreyes 2015). This situation is largely making inhabited resources susceptible to degradation.

Wildlife in Ethiopia has major aesthetic value to tourists who want to see and appreciate wild game species, especially when done within their natural environment. Wildlife resource offers a range of goods such as hides, skins, ivory, horns, meat traditional medicine, and subsistence hunting (Tefera 2011). To obtain the maximum benefit, the government is giving due attention in formulating a wildlife development and protection strategy in harmony with the country's goal, and the existing international and natural resources development and protection principles. As a result, the country's rich wildlife diversity attracts many tourists locally and internationally offering high revenue. The tourism sector in Ethiopia has been effectively recognized as an imperative sector for national revenue generation and poverty reduction by attracting low-impact high-value tourists. However, such tourism activity (wildlife tourism) is solely dependent on protected areas, primarily in national parks and wildlife reserves (Eshetu 2014).

These days, the wildlife resource in Ethiopia is facing serious threats. The wildlife populations and their management are constrained by different factors where it could be political, economic, social, and biological constraints. Among these, habitat destruction, fragmentation, political instability and policy defects, poaching, lack of commitment from government officials, scarcity of funds, expansion of large scale agriculture, illegal exploitation of available resources, and lack of skilled manpower in the field are the main ones (Tefera 2011). In addition, there exists lack of effective and sound institutional framework and legal bases for ecotourism development in the country (Teshome et al. 2020). This is attributed to the less emphasis and recognition given to ecotourism and also to lack of cohesiveness, integrity, and cooperation among the stakeholders (Eshetu 2014).

Most of the national parks and protected areas of the country have always been entangled in a multitude of problems. They are exposed to frequent fires that disturb habitats and wildlife. Due to this, Ethiopia now has the world's second-largest wildlife migration (Amare 2015a). They are also under pressure from the surrounding communities in search of arable land, pastureland, or wood for fuel and other purposes. Therefore, only a few wildlife habitats have been well-kept in their natural form. Such places are found in high mountaintops above $4000 \mathrm{~m}$, steep escarpments on the borders of the highlands, and semi-arid areas in the lower parts (Hurni et al. 2010; Bewket and Abebe 2013). To put it briefly, all the aforementioned factors are continuously degrading the wildlife resources in Ethiopia and subsequently devaluate income generating-activities from the sector.

\section{Degradation of grazing lands}

Ethiopia is known with the largest livestock population in Africa having 30.6 million Tropical Livestock Unit (TLU), and also ranked the $10^{\text {th }}$ largest in the world (Teketay 2001). According to the CSA report, the country is endowed with 30 million head of cattle, 22 million sheep, 17 million goats, 7 million equines, and 1 million camels. From this amount, about 70 to $80 \%$ of the livestock is hosted in highland areas of the country. The remaining livestock populations are grazing in the lowland areas of Afar, Somali, and Borena (CSA 2015). Livestock in Ethiopia is used as sources of several social and economic values including food, draught power, transportation, fuel, cash income, security, and for investment in both the highlands and the lowlands/pastoral farming systems. The sector contributes approximately $12-15 \%$ of the overall GDP and about $25-30 \%$ for the agricultural GDP (Beyene 2015).

Attributable to the huge livestock population, there is high pressure upon animal fodder in Ethiopia. Nationwide, livestock density data revealed that the current stocking rats on grazing/pasturelands are well above the optimum rates (Berry 2003). According to Sonneveld et al. (2010) grazing demand calculation, livestock needs to consume $2.5 \%$ of its body weight for a sustained growth, which in turn results in a consumption of $6.25 \mathrm{~kg}$ 
of forage dry matter daily for each TLU. This implies, about 191.25 million $\mathrm{kg}$ forage is need each day nationwide putting immense pressure on poorly managed grazing lands and other livestock fodders commonly used. Thus, livestock pressure on pasturelands and poor stock management systems are found to be the major sources of land degradation through soil erosion and deforestation. It has, therefore, been estimated that about $20 \%$ of the total soil erosion in Ethiopia is from degraded pasturelands (Yirdaw et al. 2017).

The expansion of grazing beyond the land's carrying capacity evidently occurs at the cost of the available natural vegetation such as forests, bushlands, and woodlands (Abdelgalil and Cohen 2010). It is mainly because forest grazing and browsing is a major source of feed for the vast livestock population. In Ethiopia, fodder derived from the forested areas provide $10 \%$ and $60 \%$ of the livestock feed during the wet and dry seasons respectively (Lemenih 2009). On the other hand, such kind of uncontrolled browsing of trees and shrubs is another aspect of overgrazing and a bald-faced cause of deforestation leading to intensive soil erosion, flooding, and associated damages (Zegeye 2018). The scarcity of grazing lands and derived livestock feed has forced the widespread use of crop residue to feed livestock. When crop residues are removed for feed and cow dung issued for fuel, the soil will lose organic matter and nutrients (Berry 2003; Belay et al. 2015). This contravenes in the natural soil nutrient cycle and seriously depletes soil quality, intensifies erosion, and eventually reduces soil productivity (Tesfa and Mekuriaw 2014).

Rangeland management in Ethiopia is a challenging task since herders own livestock privately while holding communal rights to grazing resources (Beyene 2015). In this kind of relation, individuals are usually trying to maximize private benefits by generating negative externality to other users; so that degradation of the resource is facilitated (Sikor et al. 2017). The other cause of rangeland degradation is the recurrent drought. It changes the vegetation cover, species composition (less herbaceous species richness), and decline the productive capacity of the available vegetation (Angassa 2012).

\section{Management of natural resources}

\section{Historic concerns about natural resource management}

Environmental problems such as drought, famine, and epidemics have a long history in Ethiopia which remained as a leading cause of disasters and associated human sufferings (Mohammed et al. 2017). The problem has intensified the ever-increasing rate of resource consumption and allied environmental degradations. Accordingly, the Ethiopian governments have taken several measures like tree planting, soil conservation, and others to address the problem (Mekuriaw and Hurni 2015). For the first time, tree planting activities had been started during the time of King Zera-Yacob (1434-1468). However, modern tree planting program (mainly eucalyptus tree) was started in 1895 by Emperor Menelik II primarily to address the scarcity of fuelwood (Pistorius et al. 2017).

Comparably, large-scale and community-level plantations, which still exist in many parts of the country, have been practical by the mass mobilization during the Derg regime (1974-1991). Since 1991 the FDRE government maintained emphasis, relatively better than before, on the forest sector and has taken substantial legal steps towards management and plantation. In this regard, the ratification of new forest policy and execution of forest proclamation was done (Teketay 2001). The yearly base tree planting campaign has also been introduced throughout the country where every individual was motivated to take part with the objective of inducing popular attitude towards trees (Mekuriaw and Hurni 2015). With this kind of mass mobilization, Ethiopia has made momentous improvement in tree planting year after year. For instance, over 350 million tree seedlings were planted within a day (July 19) in the year 2019, and around 3.5 billion trees were planted on 6.5 million hectares of rural lands in 3 months (from June to August) of the year. The government has further boosted plan to plant around 20 billion tree seedlings in the coming 4 years. However, continuous follow-up and protection for the trees planted is yet uncommon; so that a very small survival rate of the planted seedlings. Therefore, every individual, any of the concerned institutions, and the government authorities should all be responsible enough to take care of the plantations in the coming years.

Preventing soil erosion has long been a concern to Ethiopian farmers. Particularly in places like Konso, there has been a long tradition of soil erosion control and management practices which could be considered as one among the best practices in the field (Nyssen et al. 2010). But, at the government level, the impact of soil degradation was first recognized after the 19731974 famine that occurred in the highly degraded parts of the country such as Tigray and Wollo. Immediately, the government had started soil and water conservation (SWC) campaign to combat severe soil degradation thereby ensuring food security (Haregeweyn et al. 2015). Since 2011, the government has made the campaign to formally run every year for 2 months (January to February) throughout the country. That is, a farmer must spend at least 40 working days in a year engaged in soil and water conservation works. It is aimed at constructing the necessary physical conservation structures within identified watersheds (at a kebele level) 
under the supervision of Development Agents (DAs) and the local administrations. In practice, however, the achievement is below what was anticipated (Hurni et al. 2016).

\section{Measures suggested to reverse natural resource degradation}

Most ecological and environmental resources are scarce (Jayasuriya 2015). In order to secure continuous benefit from limited resources in Ethiopia, different policies had been designed, institutions established and various management and conservation strategies implemented. New environmentally-friendly management strategies had also been incessantly suggested by scholars to minimize resource utilization problems identified (Birhanu 2014). The most common of those natural resource appraisal, management and conservation strategies so far recommended, among others are described below.

\section{Controlling the rate of population growth}

Ethiopia is among the most populous countries in Africa where its population has been growing at a rapid rate since the 1950s. The population is increasing by over 2 million persons annually (Rahmato et al. 2007). The population in Ethiopia is not evenly distributed. Normally, the population distribution is largely influenced by altitude, climate, and soil. These physical factors could also explain why the Ethiopian highlands with moderate temperature, fertile soil, and adequate rainfall are densely populated than the other parts. To this end, about $89 \%$ of the population resides in areas above $1,500 \mathrm{~m}$ above sea level and only $11 \%$ are living below $1,500 \mathrm{~m}$ (hot climatic zone), although the hot zone encompasses more than half of Ethiopia's territory (Minale 2013). With such uneven distribution and highest growth rate, the natural resource base which supports people's livelihoods and wellbeing are being rapidly degraded (Amare and Belay 2015). Therefore, controlling the rapidly increasing population is considered as one of the most important solutions to minimize natural resource degradation.

\section{Afforestation and reforestation}

Forestry can play a substantial role in either preventing or arresting land degradation basically by avoiding or reducing soil erosion through reduced surface runoff and maintenance and/or restoration of soil organic matter and other essential nutrients (Yirdaw et al. 2017). Afforestation and reforestation activities are valuable in not only to address on-farm and off-farm dimensions of the soil erosion but are also helpful in improving soil fertility. Thus, it can possibly play its own part in reducing land and other natural resources degradations (Teketay 2001).
Forest plantations in Ethiopia, except a few recent attempts, are based almost entirely on exotic species (Marques et al. 2016). Dependence on the plantation of exotic species alone disregards the indigenous tree species which have adapted and existed in the area for millennia. These exotic monocultures are not as stable as natural ecosystems and may not give varieties of benefits. This may be considered as one form of forest degradation in terms of quality. Even the local people, in many cases, value the familiar indigenous tree species more. In the future, the inclusion of indigenous tree species along with exotic species is advisable in any of the plantation sites so as to make them ecologically sound, sustainable and be accepted by the community at large (Kassa et al. 2009).

Agroforestry Agroforestry is a land use system and one of agricultural intensification practices (Ketema et al. 2020) where woody perennials are planted and purposely integrated with crop cultivation and/or animal rearing on the same land management unit (Birhanu 2014; Marques et al. 2016). Different types of agroforestry system do exist such as alley cropping, silvopasture, home gardens, multilayer tree gardens, multipurpose trees on croplands or shelterbelts where rows of trees are planted widely spaced in between annual crops or windbreaks and buffer strips of trees in different ways (Stavi and Lal 2015).

When agroforestry systems are properly managed, it can absolutely be very beneficial for land users and their environments. It improves farm household income by setting up additional products for sale or home consumption like coffee, honey, spices, fruit, bamboo, etc. (Ketema et al. 2020). It can also enhance soil fertility in many situations and virtually slow down or reverse land degradation, sequester carbon from the atmosphere, and secure rural livelihoods (Kassa et al. 2016). The Ethiopian government in collaboration with other Nongovernmental organizations (NGOs) has made efforts to implement an agroforestry system in line with the community treeplanting programs. However, among the main challenges regarding the spread of agroforestry strategy is the lack of support for the system through public policies, which often take little notice of tree-based farming in various parts of the country (Bishaw 2009; Mbow et al. 2014).

\section{Conservation agriculture ( $C A$ )}

In Ethiopia, the traditional land use system hurts the agriculture sector and invites excessive soil erosion by wind and water (runoff), and consequently a loss of soil productivity (Bazezew 2015). As a solution for such problems, conservation agriculture (CA) should be implemented. CA is a set of practices such as conservation 
tillage, soil cover, and crop rotation aimed at increasing productivity while conserving soil (Marques et al. 2016).

Practicing CA provides ample benefits like safeguarding the environment, improving agricultural productivity, and saving labor and time. It provides a vital opportunity to reduce and recover from intensified soil erosion, nutrient depletion, and maximize crop productivity (Sanderson et al. 2013). However, many of the farmers throughout the country face risks due to soil erosion, water shortage, erratic rainfall, low crop productivity, food insecurity, extensive forest degradation, and depletion of the surrounding environment (Jouanjean et al. 2014). The risks come about due to inappropriate farm practices manifested by frequently growing cereal crops without using crop rotation, long-term tillage, and less planting of cover crops (Abebe and Sewnet 2018). The application of conservation agriculture could probably minimize all such problems (Bazezew 2015).

\section{Ensuring rights of tenure}

"Land acts as an entrance ticket into the peasantry" (Shanin 1990). Access to cultivable land is the most important natural resource for rural development and is a key factor in determining the livelihood options of the rural poor in many countries including Ethiopia (Ketema et al. 2020). The most important problems of rural land tenure system are inadequate access to land, inequitable distribution of land, tenure insecurity, fragmentation of holdings, inefficient use of land, and inappropriate land administration (Wabelo 2020).

In Ethiopia, the right to ownership of urban and rural land is exclusively vested in the state and peoples of Ethiopia. It is, thus, a public property being administered by the government and shall not subject to sale or to other means of exchange privately. Hence, Ethiopian farmers have open-ended constitutional use rights of agricultural lands but are restricted to transfer or lease to others (Ketema et al. 2020). Own-holding obtained from inheritance and/or official land distribution, cash renting and sharecropping are the major agricultural land tenure systems of the country (Alemu 2017). It is basically true that an unsecured land tenure system of such type is believed to deter long-term investments on land resources, and subdue the commitment farmers may have towards proper land management practices as it undermines the value of land ownership feeling in one way or another (Wabelo 2020). This will also undermine the value and the ownership feeling which, in turn, halt long-term investments (Mekuriaw et al. 2018). Therefore, issues of land tenure need to be secured so as to get the farmlands better managed, degradation and related consequences reduced, and its productivity improved (Tesfa and Mekuriaw 2014).

\section{Livestock improvement and grazing land management}

There was no definite policy in Ethiopia about the management of grazing lands or livestock density until the late 1990s. There was and still is a tradition of gating famed in having a large number of cattle in rural Ethiopia. Due to this, farmers with serious land shortage did not want their livestock size reduced (Bazezew 2015). Rather, they need to get more livestock fodder from communal grazing fields and vegetation from forests. It is certain that policy limiting the number of livestock is crucial to minimize overstocking on grazing lands. Improving livestock quality through hybridization is helpful to minimize livestock numbers with improved productivity. This helps to realize sustainable livestock production through grazing management and reduced livestock number with improved quality (Marques et al. 2016).

\section{Community-based ecotourism}

Ethiopia is one of the renowned nations in the world in terms of ecotourism resources (Teshome et al. 2020). The country is endowed with the vast array of historical, archaeological, cultural, and natural resources significant for the development of community-based ecotourism (Amare 2015b). Community-based ecotourism is a new approach to the tourism development process (activities) that involves the active participation of the local communities; where they can operate their lands based on their culture, natural assets, and attractions (Eshetu 2014). It fundamentality stresses out on the local community to control over and effectively involved in tourism development and management or decision-making the process thereby a major proportion of the benefits remain in the hands of the community (Teshome et al. 2020). In such instances, it becomes possible to control the undesirable social, cultural, environmental, and economic effects of the community on tourism and vice versa. At a nationwide, it offers the opportunity to get the most out of their resources and gain all the economic benefits without losing it (Amare 2015a). Most importantly, ecotourism offers improved natural resource management that leads to environmental sustainability and ensures ecologically sustainable development (Birhan and Gebreyes 2015).

Although Ethiopia possesses ample untouched resources, ecotourism is still in its infancy. Nonetheless, it holds significant potential for improvement in the future (Teshome et al. 2020). The country's quite unique biodiversity, some of which are famous safari destinations and its protected areas can offer ecotourism and leisure activities including wildlife viewing, hiking, mountain climbing, and bird watching (Eshetu 2014). With such huge potential, the country should work hard for enhanced community-based ecotourism development with progressive natural resource management. 


\section{Broadening the livelihood base and diversification}

Absorbing excess labor in rural Ethiopia is a formidable challenge the country is currently facing. Policies that go beyond food production and entail the broadening of livelihoods are crucial. This could be possible by expanding opportunities through employment generation and income diversification in various non-farm sectors and off-farm activities (Moges and Bhat 2018). Such policies will increase access to food, reduce the need for resettlement, and minimize the ominous pressure of the expanding rural population on the natural resources base (Baye 2017).

\section{Natural resource management and conflicts}

When natural resources are poorly managed, distributed, or controlled in an unfair manner, it may become the main driver of conflict and instability within the society (UNDPA and UNEP 2015). Natural resource conflicts are disagreements or disputes to get access to, or control over and use of the existing natural resources. This kind of conflicts normally emerge because people have dissimilar and inequitable uses form resources of land, water, forests, and pastures, etc. or need to manage it differently (Abebe and Bekele 2018). Disagreements may also arise when these needs are totally incompatible, or even when the primacies of certain user groups are left unconsidered in policies, programs, and projects. Generally, interest-based conflicts of such a kind are inescapable features of all societies (FAO 2017).

Conflicts will always exist to some degree in every community and have all the time been with us, due in part to the ever-increasing multiple and competing demands for natural resources. In recent years, however, the scope and magnitude of resource-based conflicts in various natural resource use systems are increasing and highly intensified (Abebe and Bekele 2018). They may occur at various levels and involve a variety of actors. Conflicts, for instance ranges from disputes among local men and women over the use of trees to conflicts among neighboring communities disputing to control over pasturelands; and then to villages, community-based organizations, governments, international agencies, and NGOs over the use and management of large forest tracts, river flows, and others. Most conflicts are characterized by the presence of multiple stakeholders who themselves may have sub-groups with varying interests (UNDPA and UNEP 2015).

Natural resource use conflicts are common occurrences in each and every part of Ethiopia. Among the prominent ones, ongoing competition over the use of rangelands between different pastoralist groups in the Middle Awash valley and Ethio-Kenya border usually raises conflicts. Similar conflicts are also common among people living around major conservation areas like the Bale Mountains
National Park, Semen Mountain National Park, and others (Abule et al. 2005). Nowadays, land-related conflicts are commonly occurring even among family members, though the conflict between neighbors is also observed (Chinigò 2014). The frequency of disputants of such kinds are increasing significantly from time to time as compared with the trend in the past. The underlying causes of these conflicts are numerous and complex posing its own effect on justice provision, community development, and social relationships (Bedasa and Hussein 2018). On the other hand, the unresolved conflict of interest on the use of Nile River among Ethiopia, Sudan, Egypt, and other riparian countries could also be taken as a noticeable example of state-wide conflicts. When such kind of conflicts are not properly addressed, it may escalate into violence and war; and thus, may cause further degradation of the environment, disrupting projects and undermining livelihoods (Fig. 4). Therefore, it is extremely difficult to properly utilize and sustainably manage resources under conflict (Kebede et al. 2014).

Resource conflicts within society can be managed and resolved. The ways by which people (even those from the same community) respond to natural resource conflicts vary noticeably (Araral 2014). As a result, every community has its own scheme of handling conflicts. Community-based conflict management and resolution mechanisms may be formal or informal, violent or peaceful, equitable, or not. Although the specific strategies and implementation may vary, societies generally rely on similar basic procedural modes to handle and resolve conflicts. The most common strategies may include avoidance, coercion, negotiation, mediation, arbitration, and adjudication (Pavanello and Levine 2011). Apart from the legal procedures, these mechanisms are common and had long been practiced as parts of the societal culture in Ethiopia (Gebre 2001).

Environmental communication using any possible media about disputing resources and other environmental affairs including all of the diverse interpersonal, group, public, organization, and mediated issues is an important exposition to disseminate factual information and create a common public understanding (Zikargae 2018). This will increase people's awareness about resource use rights, better understand the degradation tendencies, and convey to attitudinal changes. Accordingly, it will help to bring a positive change to people's resource utilization and their lifestyle in general. However, environmental communication can only be successful when it is based on sufficient, reliable and comparable information, free access to it, and unhindered information flow which ensures the exchange of environmentally relevant information (Corner et al. 2018). It should also be targeted in 


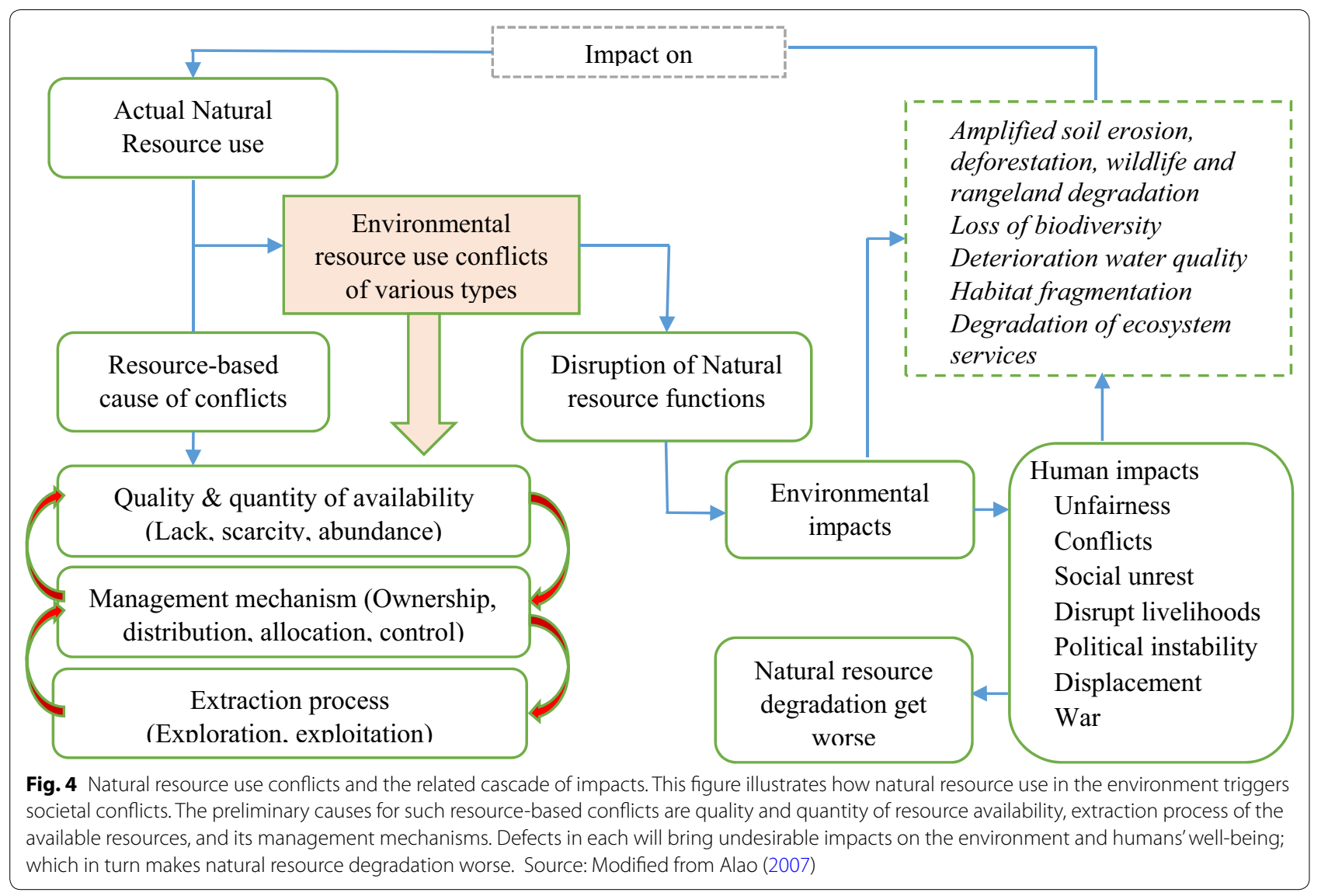

building trust among the users (Mackeracher et al. 2018); otherwise, the opposite end will become the case.

\section{Conclusion and the way forward}

A resource is a substance within the environment that is useful to people, economically and technologically feasible to access, and socially acceptable to use. Natural resources are sources of supply, support, or aid especially when it can be readily drawn upon when needed. Natural resources such as land, soil, forests, water, wildlife, rangelands, and biodiversity are considered as a resource base for the Ethiopian population. Obtaining food and securing livelihood is inextricably connected with the exploitation of these natural resources. However, the natural resources base is subjected to increasing pressure from stress caused by climate change, growing population, and improper resource utilization and management practices. This causes fast and heightened resource degradation not leaving enough time for the natural environment to restore and regenerate.

Environmental degradations caused by overexploitation of resources has reached to a level threatening the well-being of the Ethiopian population and their survival. Such poorly managed natural resources and ecosystems are likely exposing the population to longterm socio-economic risks and would have cataclysmic effects on environmental sustainability. Therefore, each and every individual should look after the natural resources, and ecosystems in any way possible so that it can continue to provide the goods and services the population needs. Besides, more policy attention from the government together with intensive research and development works has to be made in order to build an enabling environment for sustainable natural resource conservation and management.

\section{Abbreviations}

$\mathrm{BM}^{3}$ : Billion cubic meters; $\mathrm{CA}$ : Conservation agriculture; CSA: Central statistical agency; DAs: Development agents; EBI: Ethiopian Biodiversity Institute; EFAP: Ethiopian Forestry Action Program; GDP: Gross domestic product; FAO: Food and Agricultural Organization; IPCC: Intergovernmental Panel on Climate Change; LANDSAT: Land Remote-Sensing Satellite; MoA: Ministry of Agriculture; MODES: Moderate resolution Imaging Spectro-radiometer; MoWR: Ministry of Water Resource; NFPA: National Forest Priority Areas; NGOs: Non-Governmental Organizations; NMSA: National Meteorological Service Agency; SNNP: Southern Nations Nationalities and Peoples; SWC: Soil and Water Conservation; UN: United Nations; UNCCD: United Nations Convention to Combat Desertification; UNDPA: United Nations Department of Political Affairs; UNEP: United Nations Environmental Program; USAID: United States 
Agency for International Development; WBISPP: Woody Biomass Inventory and Strategic Planning Project.

\section{Acknowledgements}

The author would like to thank Tatek Belay, PhD candidate in Bahir Dar University, Ethiopia for his constructive comments and suggestions in improving the article. I would also like to appreciate Balew Demissie (PhD), a language expert and Lecturer at Addis Ababa Technology University, for giving his time in editing the paper with the necessary language improvement.

\section{Authors' contributions}

Not applicable.

\section{Funding}

There is no funding source at all.

\section{Availability of data and materials}

Not applicable.

\section{Ethics approval and consent to participate}

Not applicable.

\section{Consent for publication}

Not applicable.

\section{Competing interests}

The authors declare that there is no competing interest.

Received: 15 June 2020 Accepted: 26 October 2020

Published online: 10 November 2020

\section{References}

Abdelgalil EA, Cohen SI (2010) Modelling livestock activities and environmental sustainability: the African case. J Environ Prot (Irvine, Calif) 1:1-9. https://doi.org/10.4236/jep.2010.11001

Abebe FB, Bekele SE (2018) Challenges to National Park conservation and management in Ethiopia. J Agric Sci 10:52-62. https://doi.org/10.5539/ jas.v10n5p52

Abebe S, Sewnet A (2018) Rural land use problems and management options in Debre Tsyon Kebele. Ethiopia GeoJournal. https://doi.org/10.1007/ s10708-018-9951-7

Abera A, Yirgu T, Uncha A (2020) Impact of resettlement scheme on vegetation cover and its implications on conservation in Chewaka district of Ethiopia. Environ Syst Res. https://doi.org/10.1186/s40068-020-00164-7

Abule E, Snyman HA, Smit GN (2005) Comparisons of pastoralists perceptions about rangeland resource utilisation in the Middle Awash Valley of Ethiopia. J Environ Manag 75:21-35. https://doi.org/10.1016/j.jenvm an.2004.11.003

Adimassu Z, Mekonnen K, Yirga C, Kessler A (2014) Effect of soil bunds on runoff, soil and nutrient losses, and crop yield in the central highlands of Ethiopia. L Degrad Dev 25:554-564

Alao A (2007) Natural resources and conflict in Africa: the tragedy of endowment, 1st edn. University of Rochester Press, Rochester

Alelign G (2016) Irrigation water management at Andassa watershed. Int J Agric Environ Sci 1:33-38

Alemu MM (2017) Current trends of investment effect on land-use practices of Ethiopia. Open Access Libr J. https://doi.org/10.4236/oalib.1103326

Amare A (2015a) Wildlife resources of Ethiopia: opportunities, challenges and future directions: from ecotourism perspective: a review paper. Nat Resour 6:405-422

Amare A (2015b) Conservation challenges of Gibe Sheleko National Park, Southwestern Ethiopia. Nat Resour 6:286-289. https://doi.org/10.4236/ $\mathrm{nr} .2015 .64025$

Amare A, Belay S (2015) The environmental implication of population dynamics in Ethiopia: review. Int J Res Agric Sci 2:2348-3997

Amera T (2010) Review of the Urban Environment in Ethiopia in 2008. In: Edwards S (ed) Ethiopian Environment Review, Forum for. Forum for Environment
Amsalu A, Adem A (2009) Assessment of climate change-induced hazards, impacts and responses in the southern lowlands of Ethiopia. Cordaid and Forum for Social Studies, Addis Ababa, Ethiopia, Addis Ababa, Ethiopia

Angassa A (2012) Effects of grazing intensity and bush encroachment on herbaceous species and rangeland condition in Southern Ethiopia. L Degrad Dev Dev. https://doi.org/10.1002/ldr.2160

Angessa AT, Lemma B, Yeshitela K (2019) Land-use and land-cover dynamics and their drivers in the central highlands of Ethiopia with special reference to the Lake Wanchi watershed. GeoJournal. https://doi. org/10.1007/s10708-019-10130-1

Appannagari RR (2017) Environmental Pollution Causes and Consequences: A Study. North Asian Int Res J Soc Sci Humanit 151-161

Araral E (2014) Ostrom, Hardin and the commons: a critical appreciation and a revisionist view. Environ Sci Policy 36:11-23. https://doi.org/10.1016/j. envsci.2013.07.011

Ariti T, Van Vliet J, Verburg P (2015) Land-use and land-cover changes in the Central Rift Valley of Ethiopia: assessment of perception and adaptation of stakeholders. Appl Geogr 65:28-37. https://doi.org/10.1016/j.apgeo g.2015.10.002

Arsiso B, Tsidu M, Stoffberg G, Tadesse T (2018) Influence of urbanizationdriven land use/cover change on climate: the case of Addis Ababa, Ethiopia. Phys Chem Earth 105:212-223. https://doi.org/10.1016/j. pce.2018.02.009

Asfaw A, Demissie Y (2012) Sustainable household energy for Addis Ababa, Ethiopia. J Sustain Dev 8:1-11

Asfaw D, Neka M (2017) Factors affecting adoption of soil and water conservation practices: the case of Wereillu Woreda (District), South Wollo Zone, Amhara Region, Ethiopia. Int Soil Water Conserv Res 5:273-279. https:// doi.org/10.1016/j.iswcr.2017.10.002

Assefa E, Hans-Rudolf B (2017) Indigenous resource management practices in the Gamo Highland of Ethiopia: challenges and prospects for sustainable resource management. Sustain Sci 12:695-709. https://doi. org/10.1007/s11625-017-0468-7

Awgchew H, Gebrekidan H, Molla A (2015) Effects of municipal and industrial discharges on the quality of Beressa river water, Debre Berhan. Ethiopia 7:23-28. https://doi.org/10.5897/JENE2015

Awulachew SB, Yilma AD (2008) Statues quo analysis, characterization and assessment of performance of irrigation in Ethiopia. In: Bekele $S$, Loulseged M, Denekew A (eds) Impact of irrigation on poverty and environment in Ethiopia. International Water Management Institute (IWMI), Addis Ababa, Ethiopia, pp 342-352

Awulachew SB, Yilma AD, Loulseged M, Loiskandl W, Ayana M, Alamirew $\mathrm{T}$ (2007) Water resources and irrigation development in Ethiopia. Colombo, Sri Lanka

Azadi H, Keramati P, Taheri F, Rafiaani P, Teklemariam D, Gebrehiwotg G, Hosseininiah H, Passelb S, Lebaillyi P (2018) Agricultural land conversion: reviewing drought impacts and coping strategies. Int J Disaster Risk Reduct 31:184-195. https://doi.org/10.1016/j.ijdrr.2018.05.003

Bantider A, Hurni H, Zeleke G (2011) Responses of rural households to the impacts of population and land-use changes along the Eastern Escarpment of Wello, Ethiopia. Nor Geogr Tidsskr - Nor J Geogr 65:42-53. https ://doi.org/10.1080/00291951.2010.549954

Barrow CJ (2005) Environmental management and development, 2nd edn. Taylor and Francis Group, London and New York

Baye T (2017) Poverty, peasantry and agriculture in Ethiopia. Ann Agrar Sci 15:420-430. https://doi.org/10.1016/j.aasci.2017.04.002

Bazezew HA (2015) Adoption of conservation agricultural practices: the case of Dangila District, Amhara Region, Ethiopia. Glob J Agric Econ Ext Rural Dev 3:295-307

Bedasa NA, Hussein JW (2018) Challenges in managing land-related conflicts in East Hararghe Zone of Oromia Regional State, Ethiopia. Soc Nat Resour 31:351-366. https://doi.org/10.1080/08941920.2017.1400626

Belay K, Van RA, Poesen J, Van BS, Deckers J, Amare K (2015) Spatial analysis of land cover changes in Eastern Tigray (Ethiopia) from 1965 To 2007: are there signs of a forest transition? L Degrad Dev 26:680-689

Belay T, Mengistu DA (2019) Land use and land cover dynamics and drivers in the Muga watershed, Upper Blue Nile basin. Ethiopia Remote Sens Appl Soc Environ 15:100249. https://doi.org/10.1016/j.rsase.2019.100249

Berhanu B, Seleshi Y, Melesse AM (2014) Surface water and Ground water resources of Ethiopia: potentials and challenges of water resources 
development. In: Melesse AM, Abtew W, Setegn SG (eds) Nile river basin: ecohydrological challenges, climate change and hydropolitics. Springer, New York Dordrecht, pp 97-117

Berkes F (2010) Shifting perspectives on resource management: resilience and the reconceptualization of 'natural resources' and 'management.' Mast 9:13-40

Berry L (2003) Land degradation in Ethiopia: its extent and impact

Besada H (2017) Ethiopia: natural resource exploitation and emerging investors. Rev Gouv 14:66-87. https://doi.org/10.7202/1040637ar

Bewket W, Abebe S (2013) International journal of environmental land-use and land-cover change and its environmental implications in a tropical highland watershed, Ethiopia. Int J Environ Stud 70:126-139. https://doi.org/10.1080/00207233.2012.755765

Beyene F (2015) Incentives and challenges in community-based rangeland management: evidence from Eastern Ethiopia. L Degrad Dev 509:502-509

Bezabih B, Mosissa T (2017) Review on distribution, importance, threats and consequences of wetland degradation in Ethiopia. Int J Water Resour Environ Eng Rev 9:64-71. https://doi.org/10.5897/IJWREE2016.0697

Birhan M, Gebreyes G (2015) Review on problems, prospects and economic contribution of wildlife management and ecotourism in Ethiopia. J Vet Sci Technol. https://doi.org/10.4172/2157-7579.1000257

Birhanu A (2014) Environmental degradation and management in Ethiopian highlands: review of lessons learned. Int J Environ Prot Policy 2:24-34 https://doi.org/10.11648/j.ijepp.20140201.14

Bishaw B (2009) Deforestation and land degradation in the Ethiopian highlands: a strategy for physical recovery. Ethiop Res Innov Foresight $1: 5-18$

Campbell N, Driscoll A, Saren M (2013) Reconceptualizing resources: a critique of service-dominant logic. J Macromarketing. https://doi. org/10.1177/0276146713497755

Cassman KG, Dobermann A, Walters DT, Yang H (2003) Meeting cereal demand while protecting natural resources and improving environmental quality. Annu Rev Environ Resour 28:315-358. https://doi. org/10.1146/annurev.energy.28.040202.122858

Chinigò D (2014) Decentralization and agrarian transformation in Ethiopia: extending the power of the federal state. Crit African Stud 6:40-56. https://doi.org/10.1080/21681392.2014.853986

Cohen F, Hepburn CJ, Teytelboym A (2019) Is natural capital really substitutable? Annu Rev Environ Resour 44:425-448. https://doi.org/10.1146/ annurev-environ-101718-033055

Coria J, Sterner T (2011) Natural resource management: challenges and policy options. Annu Rev Resour Econ 3:203-230. https://doi. org/10.1146/annurev-resource-083110-120131

Corner A, Shaw C, Clarke J, Wang S (2018) Communicating environmental and sustainability science: challenges, opportunities, and the changing political context. Oxford

CSA (2015) Key findings of the 2014/2015 agricultural sample surveys. Addis Ababa, Ethiopia

Danano KA, Legesse A, Likisa D (2018) Monitoring deforestation in South Western Ethiopia using geospatial technologies. J Remote Sens GIS 7:1-5. https://doi.org/10.4172/2469-4134.1000229

De Jong R, De Bruin S, Schaepman ME, Dent D (2011) Quantitative mapping of global land degradation using Earth observations. Zurich Open Repos Arch 32:6823-6853. https://doi.org/10.1080/01431 161.2010 .512946

Dejene A (2003) Integrated natural resources management to enhance food security: the case for community-based approaches in Ethiopia. Italy, Rome

Demissie F, Yeshitilaa K, Kinduc M, Schneiderc T (2017) Land use/Land cover changes and their causes in Libokemkem District of South Gonder, Ethiopia. Remote Sens Appl Soc Environ 8:224-230. https://doi. org/10.1016/j.rsase.2017.10.001

Deribew KT, Dalacho DW (2019) Land use and forest cover dynamics in the north-eastern Addis Ababa, central highlands of Ethiopia. Environ Syst Res 8:1-18. https://doi.org/10.1186/s40068-019-0137-1

Dessie G, Kleman J (2007) Pattern and magnitude of deforestation in the South Central Rift Valley Region of Ethiopia. Mt Res Dev 27:162-168. https://doi.org/10.1659/mrd.0730

Desta H, Fetene A (2020) Land-use and land-cover change in Lake Ziway watershed of the Ethiopian Central Rift Valley Region and its environmental impacts. Land Use Policy. https://doi.org/10.1016/j. landusepol.2020.104682

Desta L, Kassie M, Benin S, Pender J (2000) Land degradation and strategies for sustainable development in the Ethiopian highlands: Amhara Region. (International Livestock Research Institute), Nairobi, Kenya

Downey L, Bonds E, Clark K (2010) Natural resource extraction, armed violence, and environmental degradation. Organ Env 23:417-445. https ://doi.org/10.1177/1086026610385903.Natural

EBI (2014) Government of the Federal Democratic Republic of Ethiopia Ethiopia's Fifth National Report to the Convention on Biological Diversity. Addis Ababa, Ethiopia

Endalew BA (2014) Impact of land use types on soil acidity in the highlands of Ethiopia: the case of Fagetalekoma district. Acad J Environ Sci 2:124-132. https://doi.org/10.15413/ajes.2013.035

Erkossa T, Williams TO, Laekemariam F (2018) Integrated soil, water and agronomic management effects on crop productivity and selected soil properties in Western Ethiopia. Int Soil Water Conserv Res 6:305-316. https://doi.org/10.1016/j.iswcr.2018.06.001

Eshetu AA (2014) Ecotourism as a viable strategy for livelihood diversification and sustainable natural resource management in Ethiopia (from eco-development paradigm point of view). J Environ Sci Water Resour 3:40-52

Evans J, Geerken R (2004) Discrimination between climate and humaninduced dryland degradation. J Arid Environ 57:535-554. https://doi. org/10.1016/S0140-1963(03)00121-6

Eyasu E (2003) National assessment on environmental roles of agriculture in Ethiopia

FAO (2017) The future of food and agriculture - Trends and challenges. FAO. Rome, 2017, Rome, Italy

FAO (1981) A framework for land evaluation: FAO Soils bulletin 32

FAO (2001) Global Forest Resources Assessment, Main Report, FAO Forestry Paper 140. FAO. 2001, Rome, Italy

FAO (2010) Global Forest Resources Assessment 2010: Country Report, Ethiopia. FRA2010/065 Rome, 2010

FAO (2015) Global forest resource assessment 2015. Desk reference. Rome, Italy

FAO (2011) Forest resources assessment working paper 177. Rome, 2011

FAO (2005) State of the World's forests, deforestation rate in Ethiopia. Rome

Gashaw T, Tulu T, Argaw M, Worqlul AW (2017) Evaluation and prediction of land use/land cover changes in the Andassa watershed, Blue Nile Basin. Ethiopia Environ Syst Res. https://doi.org/10.1186/s40068-017-0094-5

Gashaw T, Tulu T, Argaw M, Worqlul AW, Tolessa T (2018) Estimating the impacts of land use/land cover changes on ecosystem service values: the case of the Andassa watershed in the Upper Blue Nile basin of Ethiopia. Ecosyst Serv 31:219-228. https://doi.org/10.1016/j.ecose r.2018.05.001

Gashu K, Muchie Y (2018) Rethink the interlink between land degradation and livelihood of rural communities in Chilga district, Northwest Ethiopia. J Ecol Environ 42:1-11. https://doi.org/10.1186/s41610-018-0077-0

Gebre A (2001) Conflict management, resolution and institutions among the Karrayu and their Neighbours. In: Salih M (ed) African pastoralism: conflict, institutions and government. Pluto Press, London, pp 81-99

Gebre GD, Debelie HD (2015) Heavy metal pollution of soil around solid waste dumping sites and its impact on adjacent community: the case of Shashemane Open Landfill, Ethiopia. J Environ Earth Sci 5:169-178

Gebre T, Gebremedhin B (2019) The mutual benefits of promoting rural-urban interdependence through linked ecosystem services. Glob Ecol Conserv 20:e00707. https://doi.org/10.1016/j.gecco.2019.e00707

Gebreselassie S, Kirui O (2015) Economics of Land Degradation and improvement in Ethiopia. Center for development research, University of Bonn

Gebreselassie S, Kirui O, Mirzabaev A (2016) Economics of land degradation and improvement in Ethiopia. In: Nkonya Ephraim, Mirzabaev Alisher, Braun Joachim von (ed) Economics of land degradation and improvement-a global assessment for sustainable development. Springer, New York Dordrecht London, pp 401-439

Gessesse B, Bewket W, Bräuning A (2015) Model-based characterization and monitoring of runoff and soil erosion in response to land use/ land cover changes in the Modjo Watershed, Ethiopia. L Degrad Dev 26:711-724. https://doi.org/10.1002/ldr.2276

Gil R, Rico L (2009) Preventing environmental pollution through monitoring, clean technologies, education, economics and management. In: 
Laboy-Nieves EN, Schaffner FC, Abdelhadi AH, Goosen MF (eds) Environmental management, sustainable development and human health. Taylor \& Francis, London, pp 85-94

Gisladottir G, Stocking M (2005) Land degradation control and its global environmental benefits. L Degrad Dev 16:99-112. https://doi.org/10.1002/ Idr.687

Gogoi L (2013) Degradation of natural resources and its impact on environment: a study in Guwahati City, Assam, India. Int I Sci Res Publ 3:1-7

Gurmessa F (2015) Forest loss and climate change in Ethiopia. Res J Agric Environ Manag 4:216-224

Haile M, Herweg K, Brigitta S (2006) Sustainable land management—a new approach to soil and water conservation in Ethiopia. Mekelle University, Ethiopia

Hao W (2016) Study on process economics of natural resource utilization. Nat Resour 7:611-627. https://doi.org/10.4236/nr.2016.711049

Haregeweyn N, Nyssen J, Poesen J, Schu B (2015) Soil erosion and conservation in Ethiopia: a review. Prog Phys Geogr 39:750-773. https://doi. org/10.1177/0309133315598725

Hassen EE, Assen M (2017) Land use/cover dynamics and its drivers in Gelda catchment, Lake Tana watershed. Ethiopia Environ Syst Res. https://doi. org/10.1186/s40068-017-0081-x

Hubacek K, Guan D, Barua A (2007) Changing lifestyles and consumption patterns in developing countries: a scenario analysis for China and India, futures. White Rose Res Online 39:1084-1096

Hurni H (1985) Soil erosion and soil formation in agricultural eco-systems in Ethiopia and Northern Thailand. Mt Res Dev 3:131-142

Hurni $H$ (1983) Soil formation rate in Ethiopia. Addis Ababa, Ethiopia

Hurni H, Abate S, Bantider A, Debele B, Ludi E, Portner B, Yitaferu B, Zeleke G (2010) Land degradation and sustainable land management in the highlands of Ethiopia. In: Hurni H, Wiesmann U (eds) Global change and sustainable development: a synthesis of regional experiences from research partnerships. Bern, Geographica Bernensia, pp 187-207

Hurni H, Berhe W, Chadhokar P, Daniel D, Gete Z, Grunder M, Kassaye G (2016) Soil and water-conservation in ethiopia: guideline for development agents, 2nd Edition. Bern Open Publishing (BOP), Bern, Switzerland

IPCC (2014) Synthesis report. Contribution of Working Groups I, II and III to the Fifth Assessment Report of the Intergovernmental Panel on Climate Change. Geneva, Switzerland

IPCC (2007) Climate change 2007: impacts, adaptation and vulnerability. Contribution of Working Group II to the Fourth Assessment Report of the Intergovernmental Panel on Climate change. Cambridge University Press, Cambridge, New York, Melbourne, Madrid, Cape Town, Singapore, São Paolo, Delhi Cambridge

IPCC (2012) Managing the risks of extreme events and disasters to advance climate change adaptation: Special Report of the Intergovernmental Panel On Climate Change. Cambridge University Press, Mexico

Jaleta D, Mbilinyi B, Mahoo H, Lemenih M (2016) Evaluation of land use/land cover changes and eucalyptus expansion in Meja Watershed, Ethiopia. J Geogr Environ Earth Sci Int 7:1-12. https://doi.org/10.9734/JGEES I/2016/26606

Jamal S, Javed A, Khanday Y (2016) Evaluation of land degradation and socio-environmental issues: a case study of semi arid watershed in Western Rajasthan. J Environ Prot (Irvine, Calif). https://doi.org/10.4236/ jep.2016.78102

Jayasuriya RT (2015) Natural resource scarcity—classical to contemporary views. J Nat Resour Policy Res 7:221-245. https://doi.org/10.1080/19390 459.2015.1048964

Jouanjean M, Tucker J, Willem D (2014) Understanding the effects of resource degradation on socio-economic outcomes in developing countries, Shaping policy for development

Kapur R (2016) Natural resources and environmental issues. J Ecosyst Ecogr 6:2-5. https://doi.org/10.4172/2157-7625.1000196

Kassa H, Campbell B, Sandewall M, Kebede M, Tesfaye Y, Dessie G, Seifu A (2009) Building future scenarios and uncovering persisting challenges of participatory forest management in Chilimo Forest, Central Ethiopia. J Environ Manage 90:1004-1013. https://doi.org/10.1016/j.jenvm an.2008.03.009

Kassa H, Dondeyne S, Poesen J, Frankl A, Nyssen J (2016) Transition from forestto cereal-based agricultural systems: a review of the drivers of land-use change and degradation in southwest Ethiopia. Press
Kassa MA (2017) Review on environmental effects of ethiopian floriculture industry 4:1-13. https://doi.org/10.9734/ARJA/2017/31884

Kebede AG, Bekele M, Woldeamanuel T (2014) Natural resource use conflict in Bale Mountains National Park, Southeast Ethiopia. Int J Biodivers Conserv 6:814-822. https://doi.org/10.5897/JJBC2014.0766

Kebede S (2013) Groundwater in Ethiopia: features, numbers and opportunities. Springer, Heidelberg

Ketema H, Wei W, Legesse A, Wolde Z (2020) Quantifying smallholder farmers 'managed land use/land cover dynamics and its drivers in contrasting agro-ecological zones of the East African Rift. Glob Ecol Conserv 21:e00898. https://doi.org/10.1016/j.gecco.2019.e00898

Lemenih M (2009) Current and prospective economic contributions of the forestry sector in Ethiopia. In: Heckett T, Aklilu N (eds) Ethiopian forestry at crossroads: the need for a strong institution. Forum for Environment, Addis Ababa, pp 59-82

Lemenih M, Woldemariam T (2010) Review of forest, woodland and bushland resources in Ethiopia up to 2008. In: Edwards S (ed) Forum for environment: Ethiopian environment review. Eclipse Printing Press, Addis Ababa This, pp 131-173

Long H, Qu Y (2018) Land use policy land use transitions and land management: a mutual feedback perspective. Land Use Policy 74:111-120. https://doi.org/10.1016/j.landusepol.2017.03.021

Mackeracher T, Diedrich A, Gurney GG, Marshall N (2018) Who trusts whom in the Great Barrier Reef? Exploring trust and communication in natural resource management. Environ Sci Policy 88:24-31. https://doi. org/10.1016/j.envsci.2018.06.010

Marino J (2003) Threatened Ethiopian wolves persist in small isolated Afroalpine enclaves. Oryx 37:62-71. https://doi.org/10.1017/\$003060530 3000139

Marques MJ, Schwilch G, Lauterburg N, Crittenden S, Tesfai M, Stolte J, Zdruli P, Zucca C, Petursdottir T, Evelpidou N, Karkani A, Asliyilmazgil Y, Panagopoulos T (2016) Multifaceted impacts of sustainable land management in drylands: a review. Sustainability. https://doi.org/10.3390/su8020177

Mbow C, Van NM, Luedeling E, Neufeldt H, Minang PA, Kowero G (2014) ScienceDirect agroforestry solutions to address food security and climate change challenges in Africa. Curr Opin Environ Sustain 6:61-67. https:// doi.org/10.1016/j.cosust.2013.10.014

Mekonnen Z, Taddese H, Woldeamanuel T, Asfaw Z (2018) Land use and land cover changes and the link to land degradation in Arsi Negele district, Central Rift Valley, Ethiopia. Remote Sens Appl Soc Environ 12:1-9. https ://doi.org/10.1016/j.rsase.2018.07.012

Mekuriaw A (2017) Assessing the effectiveness of land resource management practices on erosion and vegetative cover using GIS and remote sensing techniques in Melaka watershed. Ethiopia Environ Syst Res. https:// doi.org/10.1186/s40068-017-0093-6

Mekuriaw A, Heinimann A, Zeleke G, Hurni H (2018) Factors influencing the adoption of physical soil and water conservation practices in the Ethiopian highlands. Int Soil Water Conserv Res 6:23-30. https://doi. org/10.1016/j.iswcr.2017.12.006

Mekuriaw A, Hurni $\mathrm{H}$ (2015) Analysing factors determining the adoption of environmental management measures on the highlands of Ethiopia. Civil Environ Res 7:61-72

Mengistu HA, Demlie MB, Abiye TA (2019) Review: Groundwater resource potential and status of groundwater resource development in Ethiopia. Hydrogeol J. https://doi.org/10.1007/s10040-019-01928-x

Meshesha DT, Tsunekawa A, Tsubo M, Ali SA, Haregeweyn N (2014) Landuse change and its socio-environmental impact in Eastern Ethiopia's highland. Reg Env Chang 14:757-768. https://doi.org/10.1007/s1011 3-013-0535-2

Minale AS (2013) Population and environment interaction: the case of gilgel abbay catchment, northwestern Ethiopia. J Environ Res Manag 4:153-162

Minstry of WaterResource (MoWR) (2002) Federal Democratic Republic of Ethiopia Ministry of Water Resources Water Sector Development Program Main Report Volume II

Moges DM, Bhat G (2018) An insight into land use/cover changes and their impacts in Rib watershed, North-western highland Ethiopia. Artic Press. https://doi.org/10.1002/ldr.3091

Mohammed Y, Yimer F, Tadesse M, Tesfaye K (2017) Meteorological drought assessment in north east highlands of Ethiopia. Int J Clim Chang Strateg Manag. https://doi.org/10.1108/IJCCSM-12-2016-0179 
Morinière L (2012) Environmentally influenced urbanisation: footprints bound for town? Urban Stud 49:435-450. https://doi.org/10.1177/0042098011 402233

Mpofu TPZ (2013) Environmental challenges of urbanization: a case study for open green space management. Res J Agric Environ Manag 2:105-110

Muleta TT, Kidane M, Bezie A (2020) The effect of land use/land cover change on ecosystem services values of Jibat forest landscape. Ethiopia GeoJournal. https://doi.org/10.1007/s10708-020-10186-4

Negassa MD, Mallie DT, Gemeda DO (2020) Forest cover change detection using Geographic Information Systems and remote sensing techniques: a spatio-temporal study on Komto Protected forest priority area, East Wollega Zone, Ethiopia. Environ Syst Res 9:1-14. https://doi. org/10.1186/s40068-020-0163-Z

Niemandt C, Greve M (2016) Agriculture, ecosystems and environment fragmentation metric proxies provide insights into historical biodiversity loss in critically endangered grassland. Agric Ecosyst Environ 235:172-181. https://doi.org/10.1016/j.agee.2016.10.018

Nigatu S (2016) Social and Environmental Impacts of Tinaw Floriculture Industry in the surrounding community, EzhaWoreda, Guraghe Zone SNNPR, Ethiopia. Unpublished Thesis, Addis Ababa

Nigussie Z, Tsunekawa A, Haregeweyn N, Adgo E, Cochraned L, Floquete A, Abele S (2018) Applying Ostrom's institutional analysis and development framework to soil and water conservation activities in northwestern Ethiopia. Land Use Policy 71:1-10. https://doi.org/10.1016/j. landusepol.2017.11.039

NMSA (2001) Federal Democratic Republic of Ethiopia Ministry of Water Resources National Meteorological Services Agency. National Meteorological Services Agency (NMSA), Ethiopia, June 2001 Addis Ababa, Ethiopia

Nune S, Kassie M, Mungatana E (2013) Forest Resource Accounts for Ethiopia. In: Hassan RM, Mungatana ED (eds) Implementing environmental accounts: case studies from Eastern and Southern Africa, eco-efficiency in industry and science 28. pp 1689-1699

Nyssen J, Clymans W, Descheemaeker K, Poesen J, Vandecasteele I, Vanmaercke M, Zenebe A, Van CM, Haile M, Haregeweyn N, Moeyersons J, Martens K, Gebreyohannes T, Deckers J, Walraevens K (2010) Impact of soil and water conservation measures on catchment hydrological response-a case in north Ethiopia. Hydrol Process 24:1880-1895. https ://doi.org/10.1002/hyp.7628

Nyssen J, Frankl A, Zenebe A, Deckers J, Poesen J (2015) Land management in the Northern Ethiopian highlands: local and global perspectives; past, present and future. L Degrad Dev 26:759-764. https://doi.org/10.1002/ Idr.2336

Nyssen J, Poesen J, Moeyersons J, Deckers J, Haile M, Lang A (2004) Human impact on the environment in the Ethiopian and Eritrean highlandsa state of the art. Earth-Sci Rev 64:273-320. https://doi.org/10.1016/ S0012-8252(03)00078-3

Olson KR, Al-kaisi M, Lal R, Cihacek L (2016) Impact of soil erosion on soil organic carbon stocks. J Soil Water Conserv 71:61-67. https://doi. org/10.2489/jswc.71.3.61A

Pacheco FAL, Fernandes LFS, Junior RFV, Valera CA, Pissarra TCT (2018) Land degradation: multiple environmental consequences and routes to neutrality. Curr Opin Environ Sci Heal. https://doi.org/10.1016/j.coesh .2018.07.002

Pavanello S, Levine S (2011) Rules of the range: natural resources management in Kenya-Ethiopia border areas

Pistorius T, Carodenuto S, Wathum G (2017) Implementing forest landscape restoration in Ethiopia. Forests 8:1-19. https://doi.org/10.3390/f8030061

Poudel K (2012) Resource management: a geographical perspective. Res Gate. https://doi.org/10.3126/ttp.v11i0.11526

Rahmato D, Admassie Y, Mekonnen Y (2007) Population, health and environment integration in Ethiopia: exploring the opportunities and challenges. Population Reference Bureau, Addis Ababa, Ethiopia, Addis Ababa, Ethiopia

Reda AH (2016) Physico-chemical characterization of tannery effluent and its impact on the nearby river. J Environ Chem Ecotoxicol 8:44-50. https:// doi.org/10.5897/JECE2015.0365

Reusing M (1998) Monitoring of forest resources in Ethiopia. Addis Ababa, Ethiopia
Reusswig F, Lotze-Campen H, Gerlinger K (2003) Changing Global Lifestyle and Consumption Patterns: The Case of Energy and Food. Potsdam Inst Clim Impact Res Glob Chang Soc Syst Dep (Research Get) 2-10

Richman MB, Leslie LM, Segele ZT (2016) Classifying drought in Ethiopia using machine learning. Procedia Comput Sci 95:229-236. https://doi. org/10.1016/j.procs.2016.09.319

Sanbata H, Asfaw A, Kumie A (2014) Indoor air pollution in slum neighbourhoods of Addis Ababa, Ethiopia. Atmos Environ 89:230-234. https://doi. org/10.1016/j.atmosenv.2014.01.003

Sanderson MA, Archer D, Hendrickson J, Kronberg S, Liebig M, Nichols K, Schmer M, Tanaka D, Aguilar J (2013) Diversification and ecosystem services for conservation agriculture: outcomes from pastures and integrated crop-livestock systems. Renew Agric Food Syst 28:129-144. https://doi.org/10.1017/S1742170512000312

Seifu W, Elias E (2018) Soil quality attributes and their role in sustainable agriculture: a review. Int J Plant Soil Sci 26:1-26. https://doi.org/10.9734/ IJPSS/2018/41589

Shanin T (1990) Defining peasants. Blackwell Publisher, Hoboken

Sikor T, He JUN, Lestrelin G (2017) Property rights regimes and natural resources: a conceptual analysis revisited. World Dev 93:337-349. https ://doi.org/10.1016/j.worlddev.2016.12.032

Siraj M, Zhang K, Xiao W, Bilal A, Gemechu S, Geda K, Yonas T, Xiaodan L (2016) Does participatory forest management save the remnant forest in Ethiopia? In: Proceedings of the National Academy of Sciences, India Section B: Biological Sciences. Springer India

Sisay A, Chalie N, Girmay Z, Takele G, Tolera A (2014) Landscape-scale soil erosion modeling and risk mapping of mountainous areas in eastern escarpment of Wondo Genet Watershed, Ethiopia. Int Res J Agric Sci Soil Sci 4:107-116. https://doi.org/10.14303/irjas.2014.040

Sonneveld BG (2002) Land under pressure: the impact of water erosion on food production in Ethiopia. Shaker, Netherlands, Netherlands

Sonneveld S, Pande S, Georgis K, Keyzer MA, Ali AS, Takele A (2010) Land degradation and overgrazing in the Afar Region, Ethiopia: a spatial analysis. In: Zdruli P, Pagliai M, Kapur S, Cano AF (eds) Land degradation and desertification: assessment, mitigation and remediation. Springer, Dordrecht, pp 97-110

Stavi I, Lal R (2015) Achieving zero net land degradation: challenges and opportunities. J Arid Environ 112:44-51. https://doi.org/10.1016/j.jarid env.2014.01.016

Taddese G (2001) Land degradation: a challenge to Ethiopia. Environ Manage 27:815-824. https://doi.org/10.1007/s002670010190

Tekle K, Hedlund L (2000) Land Cover Changes Between 1958 and 1986 in Kalu District, Southern Wello, Ethiopia. Mountain Research and Development 20: 42-51

Tefera B, Sterk G (2010) Land use policy land management, erosion problems and soil and water conservation in Fincha'a watershed, western Ethiopia. Land use policy 27:1027-1037. https://doi.org/10.1016/j.landusepol .2010.01.005

Tefera M (2011) Wildlife in Ethiopia: endemic large mammals. World J Zool 6:108-116

Tefera W, Asfaw A, Gilliland F, Worku A, Wondimagegn M, Kumie A, Samet J, Berhane K, Ababa A, Change C (2016) Indoor and outdoor air pollutionrelated health problem in Ethiopia: review of related literature. Ethiop J Heal Dev 30:5-16

Tegenu T (2010) Urbanization in Ethiopia: Study on Growth, Patterns, Functions and Alternative Policy Strategy. Unpublished thesis, Stockholm University

Teketay D (2001) Deforestation, wood famine and environmental degradation in highland ecosystems of Ethiopia: urgent need for actions. In: International Conference on African Development Archives. Paper 3. Western Michigan University ScholarWorks at WMU, Center for African Development Policy Research

Tesfa A, Mekuriaw S (2014) The effect of land degradation on farm size dynamics and crop-livestock farming system in Ethiopia: a review. Open J Soil Sci 4:1-5. https://doi.org/10.4236/ojss.2014.41001

Teshome E, Shita F, Abebe F (2020) Current community based ecotourism practices in Menz Guassa community conservation area. Ethiopia GeoJournal. https://doi.org/10.1007/s10708-020-10179-3

Teshome M (2016) Rural households 'agricultural land vulnerability to climate change in Dembia woreda. Northwest Ethiopia Environ Syst Res. https ://doi.org/10.1186/s40068-016-0064-3 
Tessema I, Simane B (2020) Smallholder Farmers ' perception and adaptation to climate variability and change in Fincha sub-basin of the Upper Blue Nile River Basin of Ethiopia. GeoJournal. https://doi.org/10.1007/s1070 8-020-10159-7

Tibebe D, Bewket W (2011) Surface runoff and soil erosion estimation using the swat model in the Keleta watershed, Ethiopia. L Degrad Dev 22:551-564. https://doi.org/10.1002/ldr.1034

Tolessa T, Dechassa C, Simane B, Alamerew B, Kidane M (2019) Land use/land cover dynamics in response to various driving forces in Didessa subbasin. Ethiopia GeoJournal. https://doi.org/10.1007/s10708-019-09990 $-4$

Tolessa T, Senbeta F, Kidane M (2017) The impact of land use/land cover change on ecosystem services in the central highlands of Ethiopia Terefe. Ecosyst Serv 23:47-54. https://doi.org/10.1016/j.ecose r.2016.11.010

Tsegaye D, Moe SR, Vedeld P, Aynekulu E (2010) Agriculture, ecosystems and environment land-use/cover dynamics in Northern Afar rangelands, Ethiopia. Agric Ecosyst Environ 139:174-180. https://doi.org/10.1016/j. agee.2010.07.017

Turner II BL, Lambin EF, Reenberg A (2007) The emergence of land change science for global. PNAS 104:20666-20672. https://www.pnas.org/cgi/ doi/https://doi.org/10.1073/pnas.0704119104

UN (2008) An overview of urbanization, internal migration, population distribution and development in the world. Department of Economic and Social Affairs United Nations Secretariat New Yo

UNCCD (2017) Global land outlook: secretariat of the United Nations Convention to Combat Desertification, First Edit. Bonn, Germany www.unccd. int

UNCCD (2015) Land matters for climate: reducing the gap and approaching the target. Bonn, Germany tel

UNDPA, UNEP (2015) Natural resources and conflict: a guide for mediation practitioners. United Nations Department of Political Affairs and United Nations Environment Programme

UNEP (2012) Global Environmental Outlook 5, Environment for the future we want. Malta by Progress Press Ltd, VALLETTA, MALTA

USAID (2006) Issues in poverty reduction and natural resource management. Washington, DC

Vorovencii I (2016) Assessing and monitoring the risk of land degradation in Baragan Plain, Romania, using spectral mixture analysis and Landsat imagery. Environ Monit Assess. https://doi.org/10.1007/s1066 $1-016-5446-5$

Wabelo TS (2020) Legal and institutional frameworks regulating rural land governance in Ethiopia: towards a comparative analysis on the best practices of other African countries. Beijing Law Rev 11:64-98. https:// doi.org/10.4236/blr.2020.111005

Wakjira FS (2006) Biodiversity and ecology of Afromontane rainforests with wild Coffea arabica L. populations in Ethiopia

WBISPP (2004) Forest resources of Ethiopia. Addis Ababa, Eethiopia

Woube M (2005) Effects of resettlement schemes on the biophysical and human environments: the case of the Gambela Region, Ethiopia. Universal Publishers Boca Raton, Florida USA, 2005, Boca Raton, Florida USA

Wright AJ, Dolman SJ, Jasny M, Parsons ECM, Schiedek D, Young SB (2013) Myth and momentum: a critique of environmental impact assessments.
J Environ Prot (Irvine, Calif) 2013:72-77. https://doi.org/10.4236/ jep.2013.48A2009

Wubie MA, Assen M (2020) Effects of land cover changes and slope gradient on soil quality in the Gumara watershed, Lake Tana basin of North-West Ethiopia. Model Earth Syst Environ 6:85-97. https://doi.org/10.1007/ s40808-019-00660-5

Wubie MA, Assen M, Nicolau MD (2016) Patterns, causes and consequences of land use/cover dynamics in the Gumara watershed of lake Tana basin, Northwestern Ethiopia. Environ Syst Res 5:1-12. https://doi. org/10.1186/s40068-016-0058-1

Yemiru T, Roos A, Campbell BM, Bohlin F (2010) Forest incomes and poverty alleviation under participatory forest management in the bale highlands, Southern Ethiopia. Int For Rev 12:66-77. https://doi.org/10.1505/ ifor.12.1.66

Yeshaneh E, Salinas JL, Blöschl G (2017) Decadal trends of soil loss and runoff in the Koga Catchment, Northwestern Ethiopia. L Degrad Dev 28:1806-1819. https://doi.org/10.1002/ldr.2375

Yirdaw E, Tigabu M, Monge A (2017) Rehabilitation of degraded dryland ecosystems-review. Silva Fenn 51. https://doi.org/https://doi. org/10.14214/sf.1673

Yonas B, Beyene F, Negatu L, Angassa A (2013) Influence of resettlement on pastoral land use and local livelihoods in southwest Ethiopia. Trop Subtrop Agroecosyst 16:103-117

Zegeye H (2018) Climate change in Ethiopia: impacts, mitigation and adaptation. Int J Res Environ Stud 5:18-35

Zeleke G, Hurni H (2001) Implications of land use and land cover dynamics for mountain resource degradation in the Northwestern Ethiopian Highlands. Mt Res Dev 21:184-191. https://doi.org/10.1659/0276-4741

Zhang W (2018) Conducting natural resource assets departure audit on leading cadres. J Serv Sci Manag 11:36-43. https://doi.org/10.4236/ jssm.2018.111004

Zikargae MH (2018) Analysis of environmental communication and its implication for sustainable development in Ethiopia. Sci Total Environ 634:1593-1600. https://doi.org/10.1016/j.scitotenv.2018.04.050

Zimmermann EW (1933) World resources and industries: a functional appraisal of the availability of agricultural and industrial resources. Harper \& Brothers, New York

\section{Publisher's Note}

Springer Nature remains neutral with regard to jurisdictional claims in published maps and institutional affiliations.

\section{Submit your manuscript to a SpringerOpen ${ }^{\circ}$ journal and benefit from:}

- Convenient online submission

- Rigorous peer review

- Open access: articles freely available online

- High visibility within the field

- Retaining the copyright to your article

Submit your next manuscript at springeropen.com 